Check for updates

Cite this: RSC Adv., 2017, 7, 41345

Received 10th July 2017

Accepted 16th August 2017

DOI: $10.1039 / c 7 r a 07581 b$

rsc.li/rsc-advances

\section{Synthesis and structural analysis of aryloxo- modified trinuclear half-titanocenes, and their use as catalyst precursors for ethylene polymerisation $\uparrow$}

\begin{abstract}
Qing Yan, Ken Tsutsumi and Kotohiro Nomura (D) *
A series of trinuclear half-titanocenes, $\left[\mathrm{Cp}^{\prime} \mathrm{TiX}_{2}\left\{\left(\mathrm{O}-2,4-\mathrm{R}_{2} \mathrm{C}_{6} \mathrm{H}_{2}\right)-6-\mathrm{CH}_{2}\right\}\right]_{3} \mathrm{~N}\left[\mathrm{X}=\mathrm{Cl}, \mathrm{R}=\mathrm{Me}, \mathrm{Cp} \mathrm{p}^{\prime}=\mathrm{Cp}(1) ; \mathrm{X}\right.$ $\left.=\mathrm{Cl}, \mathrm{R}={ }^{t} \mathrm{Bu}, \mathrm{Cp}^{\prime}=\mathrm{Cp}(4), \mathrm{Cp} *(5),{ }^{t} \mathrm{BuC}_{5} \mathrm{H}_{4}(6), 1,2,4-\mathrm{Me}_{3} \mathrm{C}_{5} \mathrm{H}_{2}(7) ; \mathrm{X}=\mathrm{Me}, \mathrm{Cp}{ }^{\prime}=\mathrm{Cp} *, \mathrm{R}=\mathrm{Me}(8),{ }^{t} \mathrm{Bu}(9)\right]$ and the related bimetallic complexes, $\left[\mathrm{Cp}^{\prime} \mathrm{TiCl}_{2}\left\{\left(\mathrm{O}-2,4-\mathrm{Me}_{2} \mathrm{C}_{6} \mathrm{H}_{2}\right)-6-\mathrm{CH}_{2}\right\}\right]\left[\mathrm{Cp} p^{\prime} \mathrm{TiCl}\left\{\left(\mathrm{O}-2,4-\mathrm{Me}_{2} \mathrm{C}_{6} \mathrm{H}_{2}\right)-6-\right.\right.$ $\left.\left.\mathrm{CH}_{2}\right\}_{2}\right] \mathrm{N}\left[\mathrm{Cp}^{\prime}=\mathrm{Cp} *(2), 1,2,4-\mathrm{Me}_{3} \mathrm{C}_{5} \mathrm{H}_{2}\right.$ (3)], have been prepared and identified. Structures of 1-5, 7 and 9 were determined by $\mathrm{X}$-ray crystallography, and all complexes fold with distorted tetrahedral geometries around titanium. These complexes (2-9) are stable in solution except the Cp analogue (1), which presents as a mixture of the trinuclear analogue (1) and the (proposed) binuclear analogue, $\mathrm{CpTiCl}_{3}$, and $\mathrm{CpTi}\left[\left\{\left(\mathrm{O}-2,4-\mathrm{Me}_{2} \mathrm{C}_{6} \mathrm{H}_{2}\right)-6-\mathrm{CH}_{2}\right\}\right]_{3} \mathrm{~N}$ in solution; there is an equilibrium between 1 and the binuclear analogue (and $\mathrm{CpTiCl}_{3}$ ) depending on the temperature, solvent and concentration. The Cp* analogues $(2,8,9)$, exhibited high catalytic activities for ethylene polymerisation in the presence of MAO cocatalyst, affording ultrahigh molecular weight polymers with uniform molecular weight distributions in most cases. [Cp*TiMe $\left.\left\{\left(\mathrm{O}-2,4-\mathrm{Me}_{2} \mathrm{C}_{6} \mathrm{H}_{2}\right)-6-\mathrm{CH}_{2}\right\}\right]_{3} \mathrm{~N}(8)$ showed the higher catalytic activities than the related mononuclear analogue, $\mathrm{Cp}^{*} \mathrm{TiCl}_{2}\left(\mathrm{O}-2-\mathrm{R}-4,6-\mathrm{Me}_{3} \mathrm{C}_{6} \mathrm{H}_{2}\right)\left(\mathrm{R}=\mathrm{Me},{ }^{t} \mathrm{Bu}\right)$; the activity by 8 in the presence of $\mathrm{Al}^{\mathrm{B} B \mathrm{~B}_{3}}-\left[\mathrm{Ph}_{3} \mathrm{C}\right]\left[\mathrm{B}\left(\mathrm{C}_{6} \mathrm{~F}_{5}\right)_{4}\right]$ cocatalysts was higher than that in the presence of $\mathrm{MAO}$.
\end{abstract}

\section{Introduction}

Transition metal catalysed olefin polymerisation is an important key reaction in the production of polyolefins [such as HDPE (high density polyethylene), LLDPE (linear low density polyethylene), isotactic polypropylene and elastomers etc.] in the chemical industry, and the market capacity still increases every year. Since the discovery of Ziegler-Natta catalysts, the design of efficient molecular catalysts has been considered as a key subject in terms of the synthesis of new polymers as well as of better control of molecular weights, compositions in the copolymerisations, and the development of more efficient processes..$^{1-5}$ Nowadays, many examples such as metallocenes, ${ }^{1 \boldsymbol{a}-\boldsymbol{d}, \boldsymbol{g}}$ linked half-metallocenes (constrained geometry type), ${ }^{1 e}$ modified half-titanocenes, ${ }^{\mathbf{4 , 5}}$ and the other transition metal complex catalysts, the so called non-metallocene

Department of Chemistry, Tokyo Metropolitan University, 1-1 Minami Osawa, Hachioji, Tokyo 192-0397, Japan. E-mail: ktnomura@tmu.ac.jp

$\dagger$ Electronic supplementary information (ESI) available: (i) Additional experiments and $\quad \mathrm{VT} \quad{ }^{1} \mathrm{H} \quad \mathrm{NMR}$ spectra of toluene- $d_{8}$ solution of $\left[\mathrm{Cp}^{\prime} \mathrm{TiCl}_{2}\left\{\left(\mathrm{O}-2,4-\mathrm{R}_{2} \mathrm{C}_{6} \mathrm{H}_{2}\right)-6-\mathrm{CH}_{2}\right\}\right]_{3} \mathrm{~N}\left[\mathrm{R}=\mathrm{Me}, \mathrm{Cp}^{\prime}=\mathrm{Cp}(\mathbf{1}) ; \mathrm{R}={ }^{t} \mathrm{Bu}, \mathrm{Cp}^{\prime}=\mathrm{Cp}\right.$ (4), $\mathrm{Cp}^{*}(5),{ }^{t} \mathrm{BuC}_{5} \mathrm{H}_{4}(6), 1,2,4-\mathrm{Me}_{3} \mathrm{C}_{5} \mathrm{H}_{2}$ (7)], $\left[\mathrm{Cp}^{\prime} \mathrm{TiCl}_{2}\left\{\left(\mathrm{O}-2,4-\mathrm{Me}_{2} \mathrm{C}_{6} \mathrm{H}_{2}\right)-6-\mathrm{CH}_{2}\right\}\right]$ $\left[\mathrm{Cp}^{\prime} \operatorname{TiCl}\left\{\left(\mathrm{O}-2,4-\mathrm{Me}_{2} \mathrm{C}_{6} \mathrm{H}_{2}\right)-6-\mathrm{CH}_{2}\right\}_{2}\right] \mathrm{N} \quad\left[\mathrm{Cp}^{\prime}=\mathrm{Cp}^{*}(2), 1,2,4-\mathrm{Me}_{3} \mathrm{C}_{5} \mathrm{H}_{2}\right.$ (3)], additional ethylene polymerization results, and tables summarized in crystal collection parameters for 1-5 and 7-9, and their structures reports. CCDC 1549581-1549587. For ESI and crystallographic data in CIF or other electronic format see DOI: $10.1039 / \mathrm{c} 7 \mathrm{ra07581b}$ type, ${ }^{1, \boldsymbol{f}, 3 \boldsymbol{B}, \boldsymbol{c}, \boldsymbol{i}-\boldsymbol{k}}$ have been reported as so called 'single-site catalysts' which facilitate the coordination and insertion polymerisation

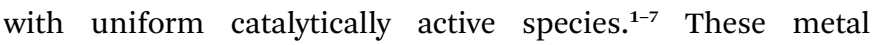
complexes are generally activated by different types of cocatalysts [such as Al alkyls, methylaluminoxane (MAO), borates etc. $]^{6,7}$ in the polymerisation to afford cationic alkyl species, which are the proposed catalytically active species in this catalysis.

Certain bimetallic olefin polymerisation catalysts (exemplified in Chart 1) have been known to exhibit unique characteristics in catalytic activity, polymer microstructure (molecular

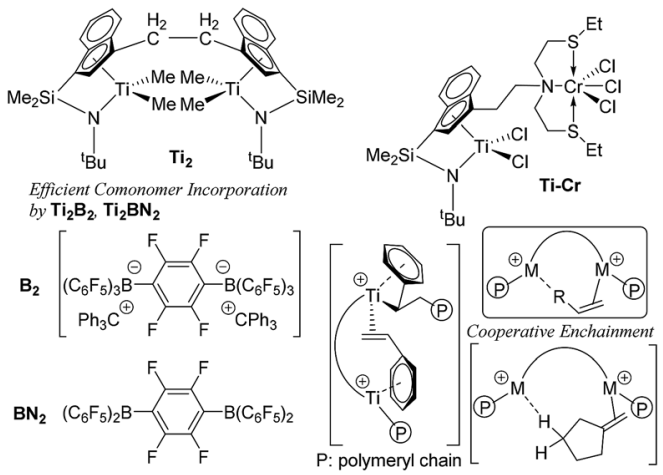

Chart 1 Typical bimetallic catalysts for efficient metal-metal cooperative effect. ${ }^{3 d, h, 8,9}$ 


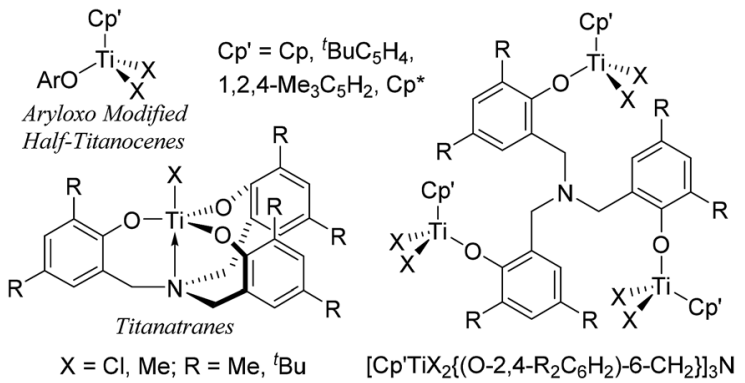

Chart 2 Reported aryloxo-modified half-titanocenes, titanatranes, and the trinuclear half-titanocenes prepared in this study.

weight, chain branching, monomer sequences, regioregularity) compared to the monomeric analogues in olefin polymerisation $^{8,9}$ due to so called metal-metal cooperative effects. ${ }^{3 d, h, 7 a, 8,9}$ This 'bimetallic effect' has been considered as due to their improved activation-transport (trapping/activation for subsequent comonomer incorporation on another metal center), ${ }^{3 \boldsymbol{d}, \boldsymbol{h}, \mathbf{8}}$ intermolecular chain transfer and/or catalyst-cocatalyst nuclearity effect on the multi-nuclear reaction sphere, ${ }^{3 d, \boldsymbol{h , 7 a , 8 , 9}}$ and should be considered to provide another possibility of the new catalyst design.

Modified (nonbridged) half-titanocenes containing anionic ancillary donor ligand $(\mathrm{Y})$ of type, $\mathrm{Cp}^{\prime} \mathrm{TiX}_{2}(\mathrm{Y})\left[\mathrm{Cp}^{\prime}=\right.$ cyclopentadienyl; $\mathrm{X}=$ halogen, alkyl; $\mathrm{Y}=$ aryloxo (Chart 2), ketimide, imidazolin-2-iminato etc.],,$^{\mathbf{4 , 5}}$ have been known to display promising characteristics especially in ethylene copolymerisation with sterically encumbered olefins, styrene, cyclic olefins. ${ }^{4}$ It has been demonstrated that both the activity and the commoner incorporation (reactivity) can be tuned by the ligand modification. ${ }^{\mathbf{4} 10}$ It has thus been simply assumed that design of multi-metallic half-titanocenes would facilitate activationtransport, intermolecular chain transfer on the multi-nuclear reaction sphere, which would lead to the better catalytic activity and/or better comonomer incorporation. As titanium complexes containing amine triphenolate ligands (titanatranes), $\operatorname{Tix}\left[\left(\mathrm{O}-2,4-\mathrm{R}_{2} \mathrm{C}_{6} \mathrm{H}_{2}\right)-6-\mathrm{CH}_{2}\right]_{3} \mathrm{~N}$ (Chart 2 left), displays unique catalysts for ethylene polymerisation, ${ }^{11}$ we thus explored synthesis and structural analysis of a series of trinuclear halftitanocenes of the type, $\left[\mathrm{Cp}^{\prime} \mathrm{TiX}_{2}\left\{\left(\mathrm{O}-2,4-\mathrm{R}_{2} \mathrm{C}_{6} \mathrm{H}_{2}\right)-6-\mathrm{CH}_{2}\right\}\right]_{3} \mathrm{~N}$ [Chart 2 right, $\mathrm{Cp}^{\prime}=\mathrm{Cp},{ }^{t} \mathrm{BuC}_{5} \mathrm{H}_{4}, 1,2,4-\mathrm{Me}_{3} \mathrm{C}_{5} \mathrm{H}_{2}, \mathrm{C}_{5} \mathrm{Me}_{5}(\mathrm{Cp} *)$; $\left.\mathrm{X}=\mathrm{Cl}, \mathrm{Me} ; \mathrm{R}=\mathrm{Me},{ }^{t} \mathrm{Bu}\right]$, and their use as the catalyst precursors for ethylene polymerisation. ${ }^{12}$ Through this study, we wish to demonstrate some unique characteristics as the olefin polymerisation catalysts which are different from the monomeric analogues.

\section{Results and discussion}

\section{Synthesis, structural analysis of trinuclear/dinuclear aryloxo-modified half-titanocenes}

Trinuclear $\left[\mathrm{CpTiCl}_{2}\left\{\left(\mathrm{O}-2,4-\mathrm{Me}_{2} \mathrm{C}_{6} \mathrm{H}_{2}\right)-6-\mathrm{CH}_{2}\right\}\right]_{3} \mathrm{~N}$ (1) could be prepared by reaction of 3 equiv. of $\mathrm{CpTiCl}_{3}$ with [(LiO-2,4$\mathrm{Me}_{2} \mathrm{C}_{6} \mathrm{H}_{2}$ )-6- $\left.\mathrm{CH}_{2}\right]_{3} \mathrm{~N}$ in $\mathrm{Et}_{2} \mathrm{O}$ in high yield (80\%, Scheme 1$)$. This is an analogous procedure for synthesis of aryloxo-modified

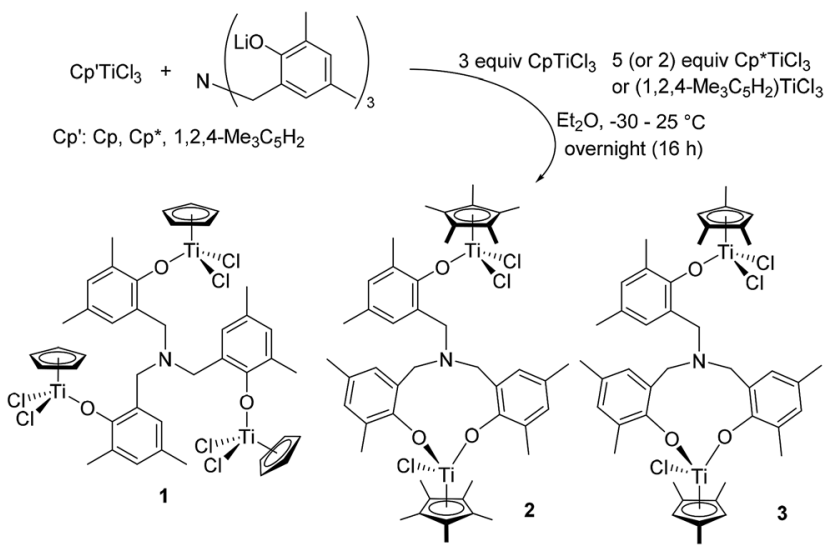

Scheme 1 Reaction of $\mathrm{Cp}^{\prime} \mathrm{TiCl}_{3}\left(\mathrm{Cp}^{\prime}=\mathrm{Cp}, \mathrm{Cp}\right.$ *, and 1,2,4- $\left.\mathrm{Me}_{3} \mathrm{C}_{5} \mathrm{H}_{2}\right)$ with $\left[\left(\mathrm{LiO}-2,4-\mathrm{Me}_{2} \mathrm{C}_{6} \mathrm{H}_{2}\right)-6-\mathrm{CH}_{2}\right]_{3} \mathrm{~N}$ in $\mathrm{Et}_{2} \mathrm{O}$.

half-titanocenes, $\mathrm{Cp}^{\prime} \mathrm{TiCl}_{2}(\mathrm{OAr}){ }^{\mathbf{1 0 i , 1 3 , 1 4}}$ and the complex could be identified by ${ }^{1} \mathrm{H}$ NMR spectrum, elemental analysis, and the structure was determined by X-ray crystallography (shown below, Fig. 2). In contrast, it turned out that the similar reactions with $\left(1,2,4-\mathrm{Me}_{3} \mathrm{C}_{5} \mathrm{H}_{2}\right) \mathrm{TiCl}_{3}$ and $\mathrm{Cp}^{*} \mathrm{TiCl}_{3}$, in place of $\mathrm{CpTiCl}_{3}$, afforded a mixture of several complexes, and the isolated complexes were bimetallic $\left[\mathrm{Cp}^{\prime} \mathrm{TiCl}_{2}\left\{\left(\mathrm{O}-2,4-\mathrm{Me}_{2} \mathrm{C}_{6} \mathrm{H}_{2}\right)-6\right.\right.$ $\left.\left.\mathrm{CH}_{2}\right\}\right]\left[\mathrm{Cp}^{\prime} \mathrm{TiCl}\left\{\left(\mathrm{O}-2,4-\mathrm{Me}_{2} \mathrm{C}_{6} \mathrm{H}_{2}\right)-6-\mathrm{CH}_{2}\right\}_{2}\right] \mathrm{N}\left[\mathrm{Cp}^{\prime}=\mathrm{Cp}^{*}(2), 1,2,4-\right.$ $\mathrm{Me}_{3} \mathrm{C}_{5} \mathrm{H}_{2}$ (3)] determined by X-ray crystallographic analyses (shown below, Fig. 3). Complexes 2 and 3 were also identified by NMR spectra and elemental analysis. The major products observed in ${ }^{1} \mathrm{H}$ NMR spectra were 2 or 3 (and the trichloride), even though the reaction was conducted with 5 equiv. of $\mathrm{Cp}^{*} \mathrm{TiCl}_{3}$ or $\left(1,2,4-\mathrm{Me}_{3} \mathrm{C}_{5} \mathrm{H}_{2}\right) \mathrm{TiCl}_{3}$ in $\mathrm{Et}_{2} \mathrm{O} \cdot{ }^{15}$ Complex 2 was also the major product observed in the ${ }^{1} \mathrm{H}$ NMR spectrum, when the reaction was conducted in toluene (shown in the ESI $\dagger$ ). ${ }^{15}$

It turned out that the $\mathrm{Cp}$ analogue (1) was unstable in solution at room temperature monitored by ${ }^{1} \mathrm{H}$ NMR spectra (Fig. 1)..$^{15}$ The toluene- $d_{8}$ solution containing 1 at $-60{ }^{\circ} \mathrm{C}$ showed a simple NMR spectrum (marked with + ) assigned as $\mathbf{1}$ (Fig. 1i, 1 $1.08 \times 10^{-3} \mathrm{M}$ ), when the NMR sample (in toluene- $d_{8}$ ) was prepared at $-30{ }^{\circ} \mathrm{C}$ (in the drybox) and kept cool until the measurement. However, the spectrum at $-30{ }^{\circ} \mathrm{C}$ (Fig. 1a and j) showed resonances ascribed to $\mathbf{1}$ in addition to the others (including $\mathrm{CpTiCl}_{3}$ ), as mentioned below. Upon increasing at $-40{ }^{\circ} \mathrm{C}$ and $0{ }^{\circ} \mathrm{C}$ (Fig. 1c and d), resonance ascribed to $\mathrm{CpTiCl}_{3}$ (marked with $\boldsymbol{\nabla}$ ) was appeared in addition to resonances ascribed to (probably) bimetallic species (marked with $\bigcirc$ estimated by the resonances by 2 and 3, two doublets at 3.7-4.0 ppm and two singlets at 5.9-6.1 ppm). The intensities ascribed to $\mathrm{CpTiCl}_{3}$ (and assumed bimetallic species) increased at $0{ }^{\circ} \mathrm{C}$. The other resonances ascribed to titanatrane, CpTi[\{(O-2,4$\mathrm{Me}_{2} \mathrm{C}_{6} \mathrm{H}_{2}$ )-6- $\left.\left.\mathrm{CH}_{2}\right\}_{3} \mathrm{~N}\right]^{16}$ (marked with \#) were also appeared upon increasing at $25{ }^{\circ} \mathrm{C}$ with increasing the intensities ascribed to both $\mathrm{CpTiCl}_{3}$ and the assumed bimetallic species (Fig. 1e). Upon cooling, the intensity of resonances ascribed to $\mathrm{CpTiCl}_{3}$ etc. decreased and the solution at $-60{ }^{\circ} \mathrm{C}$ showed the original spectrum assigned to 1 in addition of $\mathrm{CpTiCl}_{3}$ and $\mathrm{CpTi}[\{(\mathrm{O}-2,4-$ $\mathrm{Me}_{2} \mathrm{C}_{6} \mathrm{H}_{2}$ )-6- $\left.\mathrm{CH}_{2}\right\}_{3} \mathrm{~N}$ ] with ratio of ca. $35: 45: 20$ (Fig. 1h), which 


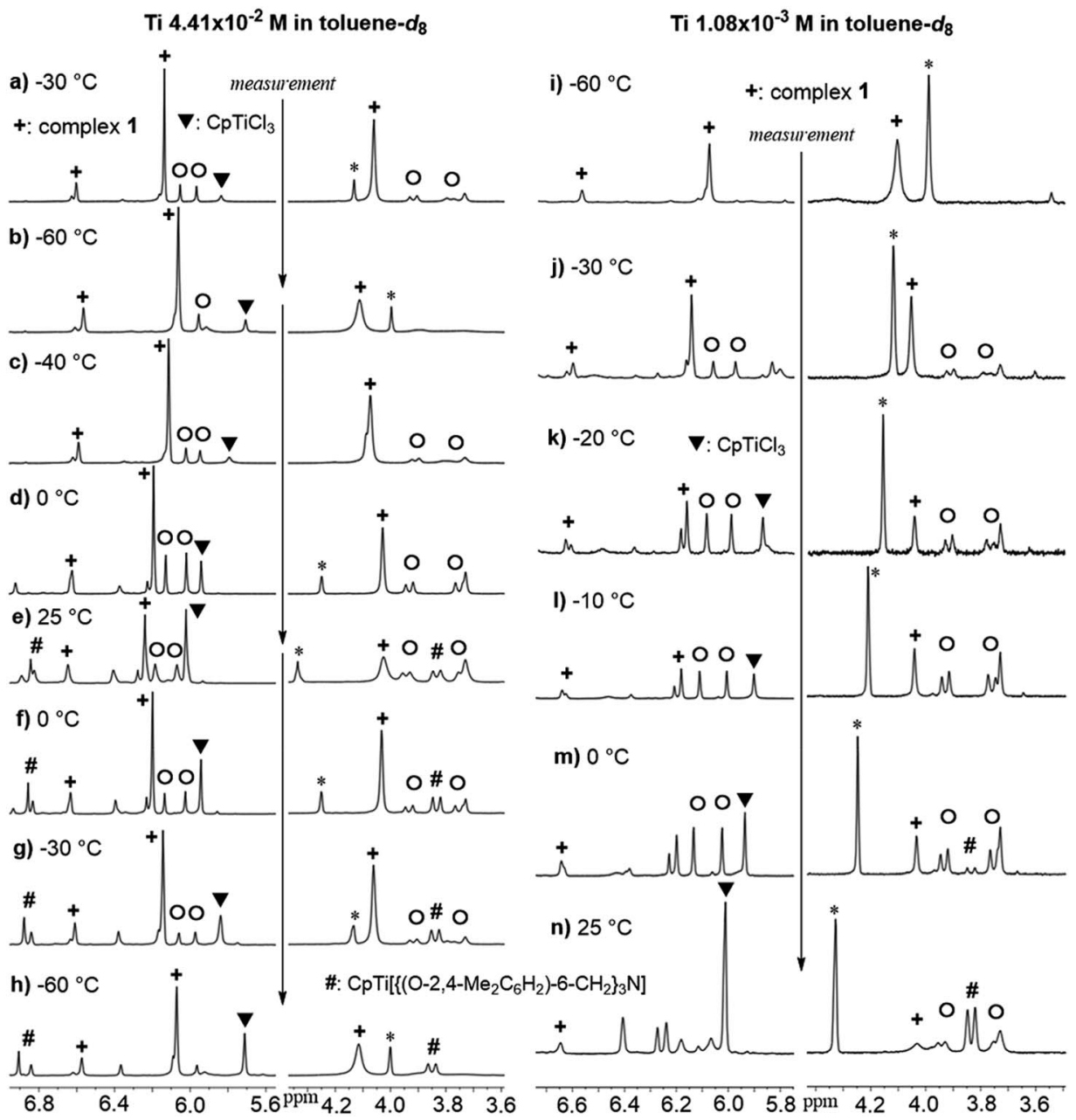

Fig. 1 Variable Temperature (VT) ${ }^{1} \mathrm{H}$ NMR spectra of toluene-d solution containing $\left[\mathrm{CpTiCl} 2\left\{\left(\mathrm{O}-2,4-\mathrm{Me}_{2} \mathrm{C}_{6} \mathrm{H}_{2}\right)-6-\mathrm{CH}_{2}\right\}\right]_{3} \mathrm{~N}(1)$. Left: VT NMR spectra with rather high Ti concentration (Ti $\left.4.41 \times 10^{-2} \mathrm{M}\right)$. Right: The VT NMR spectra with rather low Ti concentration (Ti $\left.1.08 \times 10^{-3} \mathrm{M}\right)$. The more data are shown in the ESI. $\dagger^{15}$ Complex $1(+), \mathrm{CpTiCl}_{3}(\boldsymbol{\nabla}), \mathrm{CpTi}\left[\left\{\left(\mathrm{O}-2,4-\mathrm{Me}_{2} \mathrm{C}_{6} \mathrm{H}_{2}\right)-6-\mathrm{CH}_{2}\right\}_{3} \mathrm{~N}\right]$ (\#), assumed bimetallic species $(\mathrm{O})$. *Impurity.

would be well suggest that the titanatrane was formed by dissociation of $\mathrm{CpTiCl}_{3}$ from 1. The similar spectra were observed when the sample of $\mathbf{1}$ was prepared with rather low concentration (Fig. 1 right), although the spectrum measured at $-60{ }^{\circ} \mathrm{C}$ showed simple resonances ascribed to 1 (Fig. 1i).

Moreover, the intensity of resonances ascribed to $\mathrm{CpTiCl}_{3}$ (and those in assumed bimetallic species) increased upon increasing the temperature (from $-30{ }^{\circ} \mathrm{C}$ through $-10{ }^{\circ} \mathrm{C}$, Fig. $1 \mathrm{j}-\mathrm{l}$ ), along with decreasing the intensities of resonances ascribed to $1 .^{15}$ Resonances ascribed to titanatrane were observed at $0{ }^{\circ} \mathrm{C}$ and the intensities increased at $25^{\circ} \mathrm{C}$. It was thus revealed from these spectra that the ratios $\left(\mathbf{1}, \mathrm{CpTiCl}_{3}\right.$, titanatrane) were also affected by the Ti concentrations. It was also revealed that the ratio was also affected by the solvent (shown in the ESI $\dagger$ ). ${ }^{15}$ The integration ratios of $\mathrm{CpTiCl}_{3}$ and the assumed bimetallic species were relatively close to $1: 1$, and the ratios were affected by the temperature measured and were reversible, except once formed titanatrane, $\mathrm{CpTi}\left[\left\{\left(\mathrm{O}-2,4-\mathrm{Me}_{2} \mathrm{C}_{6} \mathrm{H}_{2}\right)-6-\mathrm{CH}_{2}\right\}_{3} \mathrm{~N}\right] \cdot{ }^{15,16}$

These results suggest a presence of an equilibrium between 1 and the assumed bimetallic species, probably $\left[\mathrm{CpTiCl}_{2}\{(\mathrm{O}-2,4-\right.$
$\left.\left.\left.\mathrm{Me}_{2} \mathrm{C}_{6} \mathrm{H}_{2}\right)-6-\mathrm{CH}_{2}\right\}\right]\left[\operatorname{CpTiCl}\left\{\left(\mathrm{O}-2,4-\mathrm{Me}_{2} \mathrm{C}_{6} \mathrm{H}_{2}\right)-6-\mathrm{CH}_{2}\right\}_{2}\right] \mathrm{N}, \quad$ with dissociation of $\mathrm{CpTiCl}_{3}$, as depicted in Scheme 2. The results also suggest that the further reaction could afford the titanatrane, CpTi $\left[\left\{\left(\mathrm{O}-2,4-\mathrm{Me}_{2} \mathrm{C}_{6} \mathrm{H}_{2}\right)-6-\mathrm{CH}_{2}\right\}_{3} \mathrm{~N}\right]$, with further dissociation of $\mathrm{CpTiCl}_{3}$ that is very stable in solution (Scheme 2). This

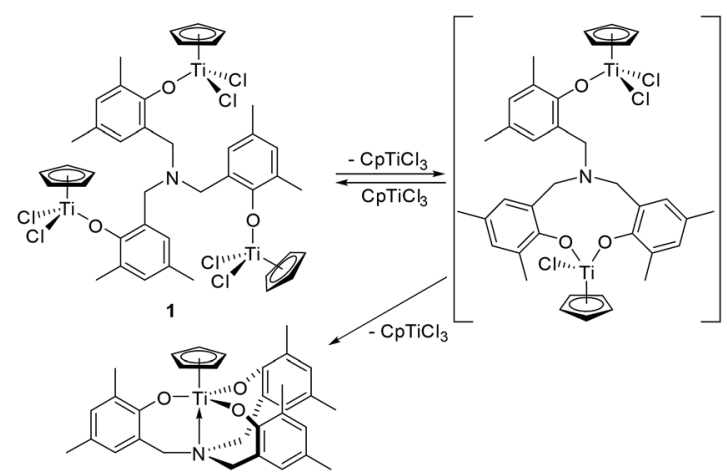

Scheme 2 Proposed equilibrium in solution containing 1 (observed in NMR spectra, Fig. 1). 


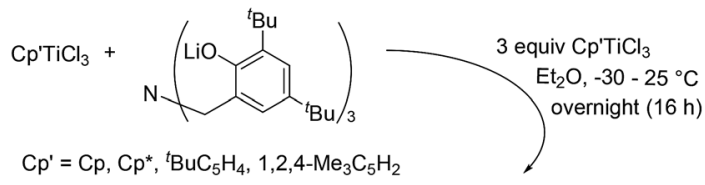

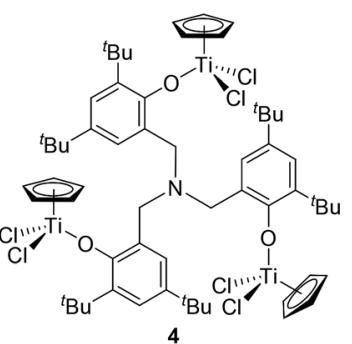

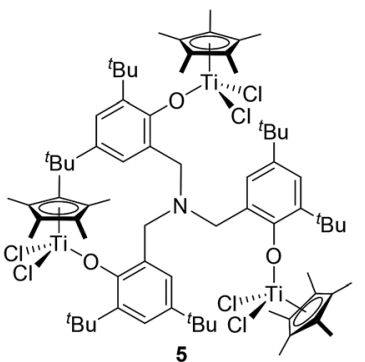

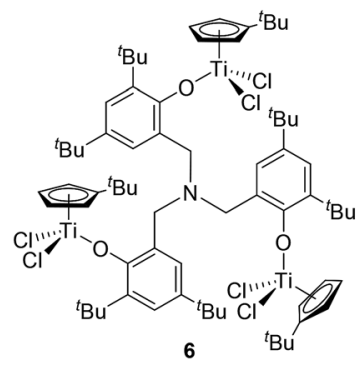

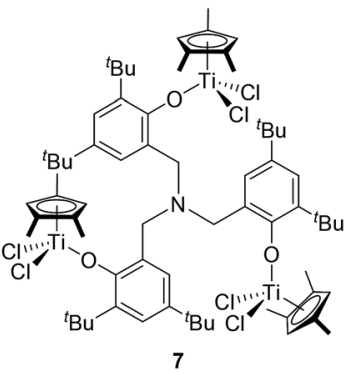

Scheme 3 Synthesis of $\left[\mathrm{Cp}^{\prime} \mathrm{TiCl}_{2}\left\{\left(\mathrm{O}-2,4-{ }^{\mathrm{t}} \mathrm{Bu}_{2} \mathrm{C}_{6} \mathrm{H}_{2}\right)-6-\mathrm{CH}_{2}\right\}\right]_{3} \mathrm{~N}$.

assumption would be able to explain why the bimetallic 2 and 3 were isolated in the reactions of $\mathrm{Cp}^{\prime} \mathrm{TiCl}_{3}\left(\mathrm{Cp}^{\prime}=\mathrm{Cp}^{*}, 1,2,4-\right.$ $\mathrm{Me}_{3} \mathrm{C}_{5} \mathrm{H}_{2}$, Scheme 1). It also turned out that once formed 2 and
3 are, in contrast, relatively stable even in toluene- $d_{8}$ upon heating at $80{ }^{\circ} \mathrm{C}$ for $30 \mathrm{~min}$ (shown in the ESI $\dagger$ ). ${ }^{15}$

It turned out that reaction of $\mathrm{Cp}^{\prime} \mathrm{TiCl}_{3}\left(\mathrm{Cp}^{\prime}=\mathrm{Cp}, \mathrm{Cp}\right.$, $\left.{ }^{t} \mathrm{BuC}_{5} \mathrm{H}_{4}, 1,2,4-\mathrm{Me}_{3} \mathrm{C}_{5} \mathrm{H}_{2}\right)$ with [( $\left.\left.\mathrm{LiO}-2,4{ }^{-}{ }^{t} \mathrm{Bu}_{2} \mathrm{C}_{6} \mathrm{H}_{2}\right)-6-\mathrm{CH}_{2}\right]_{3} \mathrm{~N}$ in $\mathrm{Et}_{2} \mathrm{O}$ afforded the corresponding trinuclear complexes, $\left[\mathrm{Cp}^{\prime} \mathrm{TiCl}_{2}\left\{\left(\mathrm{O}-2,4-{ }^{t} \mathrm{Bu}_{2} \mathrm{C}_{6} \mathrm{H}_{2}\right)-6-\mathrm{CH}_{2}\right\}\right]_{3} \mathrm{~N}\left[\mathrm{Cp}^{\prime}=\mathrm{Cp}(4), \mathrm{Cp}^{*}(5)\right.$, ${ }^{t} \mathrm{BuC}_{5} \mathrm{H}_{4}$ (6), 1,2,4- $\mathrm{Me}_{3} \mathrm{C}_{5} \mathrm{H}_{2}$ (7), Scheme 3], and the resultant complexes could be identified by NMR spectra and elemental analysis; their structures $(\mathbf{4}, \mathbf{5}, \mathbf{7})$ were determined by X-ray crystallography (shown below, Fig. 2). In contrast to the methyl analogue (1), the tert-Bu complex (4) is relatively stable and no significant differences in the ${ }^{1} \mathrm{H}$ NMR spectra (in toluene- $d_{8}$ ) were observed upon heating at $80{ }^{\circ} \mathrm{C}$ for $30 \mathrm{~min}$ (shown in the ESI, Fig. S2-S6 $\dagger$ )..$^{15}$ No additional resonances were observed when the toluene- $d_{8}$ solution containing the $\mathrm{Cp}^{*}$ analogue (5) was heated at $80{ }^{\circ} \mathrm{C}$ for $30 \mathrm{~min}$ (Fig. S2-S7, in the ESI $\dagger$ ),$^{15}$ whereas certain additional resonances (but very small amount) were observed when the toluene- $d_{8}$ solutions containing the ${ }^{t} \mathrm{BuC}_{5} \mathrm{H}_{4}$ analogue (6) and the 1,2,4- $\mathrm{Me}_{3} \mathrm{C}_{5} \mathrm{H}_{2}$ analogue (7) were heated under the same conditions (Fig. S2S9†). ${ }^{15}$ The observed difference in the stability may be somewhat related to the stability and uniformity of the catalytically active species as described below.

Fig. 2 shows ORTEP drawings for the trinuclear halftitanocenes, $\quad\left[\mathrm{CpTiCl}_{2}\left\{\left(\mathrm{O}-2,4-\mathrm{Me}_{2} \mathrm{C}_{6} \mathrm{H}_{2}\right)-6-\mathrm{CH}_{2}\right\}\right]_{3} \mathrm{~N} \quad(\mathbf{1}) \quad$ and $\left[\mathrm{Cp}^{\prime} \mathrm{TiCl}_{2}\left\{\left(\mathrm{O}-2,4{ }^{-}{ }^{t} \mathrm{Bu}_{2} \mathrm{C}_{6} \mathrm{H}_{2}\right)-6-\mathrm{CH}_{2}\right\}\right]_{3} \mathrm{~N}\left[\mathrm{Cp}^{\prime}=\mathrm{Cp}(4), \mathrm{Cp}^{*}(5)\right.$, $\left.1,2,4-\mathrm{Me}_{3} \mathrm{C}_{5} \mathrm{H}_{2}(7)\right]$ determined by X-ray crystallography, ${ }^{17}$ and the selected bond distances and the angles are summarised in
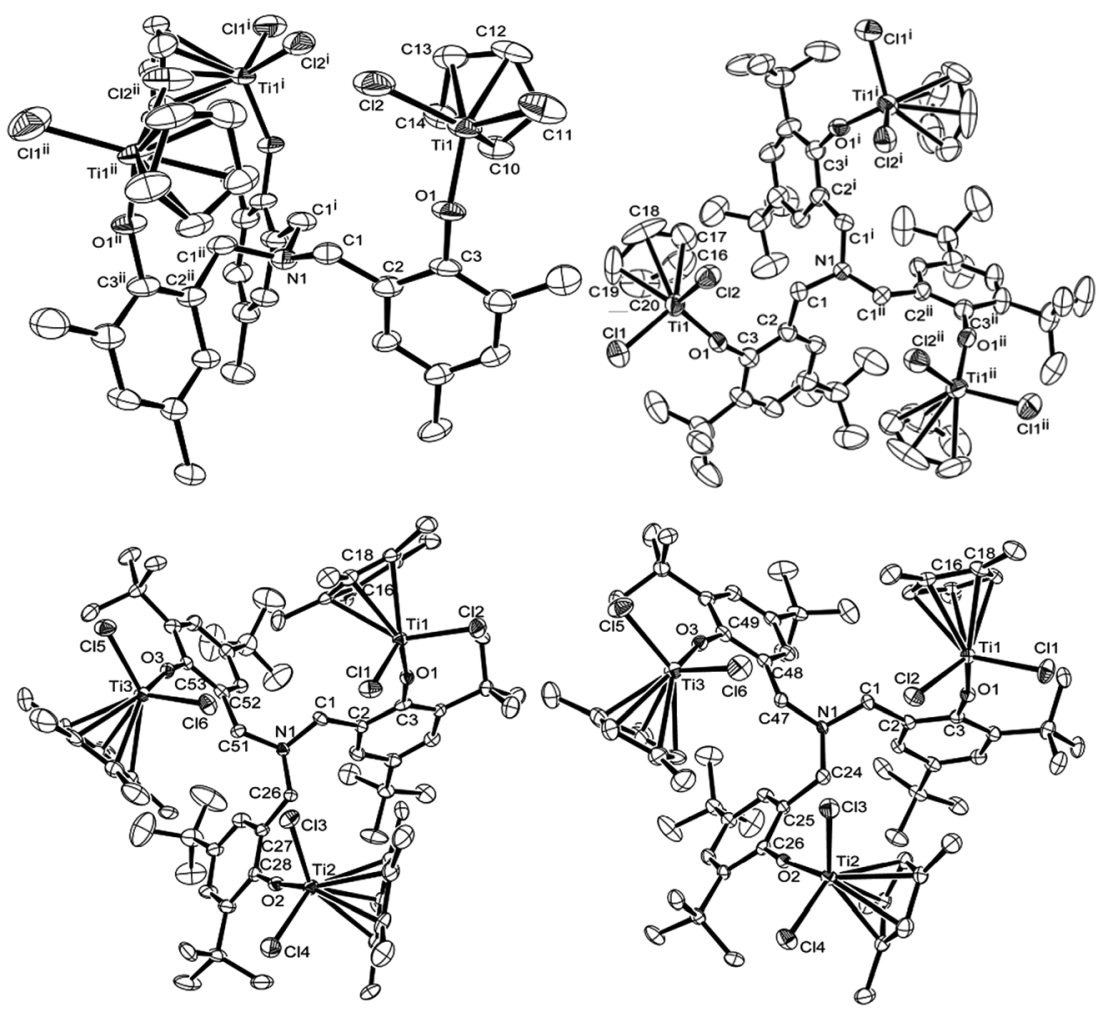

Fig. 2 ORTEP drawings for $\left[\mathrm{CpTiCl} 2\left\{\left(\mathrm{O}-2,4-\mathrm{Me}_{2} \mathrm{C}_{6} \mathrm{H}_{2}\right)-6-\mathrm{CH}_{2}\right\}\right]_{3} \mathrm{~N}\left(1\right.$, top left), $\left[\mathrm{Cp}^{\prime} \mathrm{TiCl}_{2}\left\{\left(\mathrm{O}-2,4-{ }^{t} \mathrm{Bu}_{2} \mathrm{C}_{6} \mathrm{H}_{2}\right)-6-\mathrm{CH}_{2}\right\}\right]_{3} \mathrm{~N}\left[\mathrm{Cp}{ }^{\prime}=\mathrm{Cp}(4\right.$, top right), $\mathrm{Cp} *\left(5\right.$, bottom left), $1,2,4-\mathrm{Me}_{3} \mathrm{C}_{5} \mathrm{H}_{2}$ (7, bottom right)]. Thermal ellipsoids are drawn at the $50 \%$ probability level, and $\mathrm{H}$ atoms are omitted for clarity. ${ }^{17}$ 
Table 1 Selected bond distances and angles for $\left[\mathrm{Cp}^{\prime} \mathrm{TiCl}_{2}\left\{\left(\mathrm{O}-2,4-\mathrm{R}_{2} \mathrm{C}_{6} \mathrm{H}_{2}\right)-6-\mathrm{CH}_{2}\right\}\right]_{3} \mathrm{~N}\left[\mathrm{R}=\mathrm{Me}, \mathrm{Cp}{ }^{\prime}=\mathrm{Cp}(1) ; \mathrm{R}={ }^{t} \mathrm{Bu}, \mathrm{Cp}{ }^{\prime}=\mathrm{Cp}(4), \mathrm{Cp} *(5), 1,2,4-\right.$ $\left.\mathrm{Me}_{3} \mathrm{C}_{5} \mathrm{H}_{2}(7)\right] .{ }^{17}$

\begin{tabular}{|c|c|c|c|c|c|c|c|}
\hline Complex $\mathrm{Cp}^{\prime}: \mathrm{R}$ & $1 \mathrm{Cp}: \mathrm{Me}$ & $4 \mathrm{Cp}:{ }^{t} \mathrm{Bu}$ & $5 \mathrm{Cp}^{*}:{ }^{t} \mathrm{Bu}$ & 7 1,2,4- $\mathrm{Me}_{3} \mathrm{C}_{5} \mathrm{H}_{2}:{ }^{t} \mathrm{Bu}$ & $\begin{array}{l}\mathrm{CpTiCl}_{2} \\
\left(\mathrm{O}-2,6-\mathrm{Et}_{2} \mathrm{C}_{6} \mathrm{H}_{3}\right)^{a}\end{array}$ & $\begin{array}{l}\mathrm{CpTiCl}_{2} \\
\left(\mathrm{O}-2,6-{ }^{\mathrm{i}} \mathrm{Pr}_{2} \mathrm{C}_{6} \mathrm{H}_{3}\right)^{b}\end{array}$ & $\begin{array}{l}\mathrm{Cp} * \mathrm{TiCl}_{2} \\
\left(\mathrm{O}-2,6{ }^{-}{ }^{-} \mathrm{Bu}_{2} \mathrm{C}_{6} \mathrm{H}_{3}\right)^{c}\end{array}$ \\
\hline \multicolumn{8}{|c|}{ Bond distances $(\AA)$} \\
\hline $\operatorname{Ti}(1)-\mathrm{Cl}(1)$ & $2.252(3)$ & $2.2649(19)$ & $2.2616(14)$ & $2.2615(12)$ & $2.2680(10)$ & $2.262(1)$ & $2.2674(10)$ \\
\hline $\operatorname{Ti}(1)-\mathrm{Cl}(2)$ & $2.249(2)$ & $2.2361(16)$ & $2.2702(14)$ & $2.2475(8)$ & $2.2710(10)$ & $2.262(1)$ & $2.2674(10)$ \\
\hline $\operatorname{Ti}(1)-O(1)$ & $1.788(4)$ & $1.774(3)$ & $1.790(3)$ & $1.779(2)$ & $1.7781(18)$ & $1.760(4)$ & $1.804(2)$ \\
\hline $\mathrm{Ti}-\mathrm{C}$ in $\mathrm{Cp}^{\prime}$ & $\begin{array}{l}2.330(9) ; \\
2.356(9) \\
\mathrm{Ti}-\mathrm{C}(10) \\
-\mathrm{C}(12)\end{array}$ & $\begin{array}{l}2.339(8) ; \\
2.336(5), \\
\mathrm{Ti}-\mathrm{C}(16) ; \\
-\mathrm{C}(18)\end{array}$ & $\begin{array}{l}2.348(4) ; 2.415(5) \\
\text { Ti-C(16); }-\mathrm{C}(18)\end{array}$ & $\begin{array}{l}2.343(3) ; 2.393(3), \\
\mathrm{Ti}-\mathrm{C}(16) ;-\mathrm{C}(18)\end{array}$ & $\begin{array}{l}2.351(3) ; 2.325(3) \\
\mathrm{Ti}-\mathrm{C}(1) ;-\mathrm{C}(3)\end{array}$ & $\begin{array}{l}2.282(8) ; 2.325(5), \\
\mathrm{Ti}-\mathrm{C}(1) ;-\mathrm{C}(3)\end{array}$ & $\begin{array}{l}2.359(4) ; \\
2.370(3), \\
\text { Ti-C(1);-C(3) }\end{array}$ \\
\hline \multicolumn{8}{|l|}{ Bond angles $\left({ }^{\circ}\right)$} \\
\hline $\mathrm{Cl}(1)-\mathrm{Ti}(1)-\mathrm{Cl}(2)$ & $103.41(11)$ & $101.52(6)$ & $101.11(5)$ & $101.14(4)$ & $102.24(3)$ & $104.23(7)$ & $98.10(4)$ \\
\hline $\mathrm{Cl}(1)-\mathrm{Ti}-\mathrm{O}(1)$ & $104.50(19)$ & $104.37(10)$ & 103.02(10) & $103.89(8)$ & $103.35(6)$ & $102.53(9)$ & $103.22(6)$ \\
\hline $\mathrm{Cl}(2)-\mathrm{Ti}-\mathrm{O}(1)$ & $102.58(15)$ & $103.17(12)$ & $103.27(10)$ & $104.09(8)$ & $101.97(7)$ & $102.53(9)$ & $103.22(6)$ \\
\hline Ti(1)-O-C(3) & $149.9(6)$ & $157.6(2)$ & $169.3(3)$ & $165.4(2)$ & $\begin{array}{l}\text { 161.37(17), } \\
\text { Ti-O-C(11) }\end{array}$ & $\begin{array}{l}\text { 163.0(4), } \\
\text { Ti-O-C(6) }\end{array}$ & $\begin{array}{l}\text { 155.5(2), } \\
\text { Ti-O-C(7) }\end{array}$ \\
\hline$C(1)-N(1)-C(1)^{i}$ & $110.6(5)$ & $112.5(2)$ & $\begin{array}{l}110.5(3), \\
C(1)-N(1)-C(26)\end{array}$ & $\begin{array}{l}\text { 110.1(2), } \\
\mathrm{C}(1)-\mathrm{N}(1)-\mathrm{C}(24)\end{array}$ & & & \\
\hline $\mathrm{N}(1)-\mathrm{C}(1)-\mathrm{C}(2)$ & $112.8(6)$ & $112.3(4)$ & $111.9(3)$ & 112.5(3) & & & \\
\hline
\end{tabular}

Table 1. The complex 1 folds distorted tetrahedral geometry around titanium, as observed in the mononuclear half-titanocenes. ${ }^{10 i, 14}$ No significant differences in the bond distances and angles were observed in each titanium complex. The Ti-Cl bond distances in 1 [2.252(3), 2.249(2) $\AA]$ are slightly shorter than those in the mononuclear analogues, $\mathrm{CpTiCl}_{2}\left(\mathrm{O}-2,6-\mathrm{Et}_{2} \mathrm{C}_{6} \mathrm{H}_{3}\right)^{14 d}$ and $\mathrm{CpTiCl}_{2}\left(\mathrm{O}-2,6-{ }^{\mathrm{i}} \mathrm{Pr}_{2} \mathrm{C}_{6} \mathrm{H}_{3}\right)^{14 c}$ [2.262(1)-2.2710(10) $\left.\mathrm{A}\right]$, but within the range of those in the $\mathrm{Cp}$ analogues containing chlorinated phenoxides like $\mathrm{CpTiCl}_{2}\left(\mathrm{OC}_{6} \mathrm{Cl}_{5}\right)$, [2.2492(17), 2.261(3) $\AA]^{10 i}$ The Ti-O bond distance $[1.788(4) \AA]$ is slightly longer than those in $\mathrm{CpTiCl}_{2}\left(\mathrm{O}-2,6-\mathrm{Et}_{2} \mathrm{C}_{6} \mathrm{H}_{3}\right)^{14 d}$ and $\mathrm{CpTiCl}_{2}(\mathrm{O}-$ 2,6- $\left.{ }^{\mathrm{i}} \mathrm{Pr}_{2} \mathrm{C}_{6} \mathrm{H}_{3}\right)^{14 c}$ [1.7781(18), 1.760(4) $\mathrm{\AA}$, respectively] but shorter than those in $\mathrm{CpTiCl}_{2}\left(\mathrm{OC}_{6} \mathrm{Cl}_{5}\right)$ [1.814(4) $\left.\mathrm{\AA}\right]$ and $\mathrm{CpTiCl}_{2}(\mathrm{O}-2,6$ $\left.\mathrm{Cl}_{2} \mathrm{C}_{6} \mathrm{H}_{3}\right)$ [1.8091(12) $\left.\mathrm{A}\right] ;^{10 i}$ the bond distance is, however,

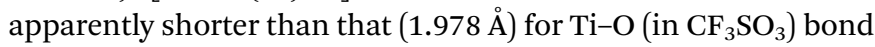
distance in $\mathrm{Cp}$ * TiMe $\left(\mathrm{CF}_{3} \mathrm{SO}_{3}\right)\left(\mathrm{O}-2,6-{ }^{\mathrm{i}} \mathrm{Pr}_{2} \mathrm{C}_{6} \mathrm{H}_{3}\right)^{14 e}$ due to the $\pi$-donation from oxygen to titanium. The Ti-O-C(3) (in phenyl) bond angle is $149.9(6)^{\circ}$, which is smaller than those in $\mathrm{CpTiCl}_{2}\left(\mathrm{O}-2,6-\mathrm{Et}_{2} \mathrm{C}_{6} \mathrm{H}_{3}\right)^{14 d}$ and $\mathrm{CpTiCl}_{2}\left(\mathrm{O}-2,6-{ }^{\mathrm{i}} \mathrm{Pr}_{2} \mathrm{C}_{6} \mathrm{H}_{3}\right)^{14 c}$ $\left[161.37(17), 163.0(4)^{\circ}\right.$, respectively] and those in the $\mathrm{Cp}$ analogues containing chlorinated phenoxides [151.5(3)$\left.152.96(10)^{\circ}\right] . .^{10 i}$ The $\mathrm{Cl}(1)-\mathrm{Ti}-\mathrm{Cl}(2)$ bond angle $\left[103.41(11)^{\circ}\right]$ is within the range of the reported $\mathrm{Cp}$ analogues [101.75(2)$\left.104.23(7)^{\circ}\right]^{10 i, 14 c, d}$

The complexes 4, $\mathbf{5}$ and $\mathbf{7}$ also fold a distorted tetrahedral geometry around titanium. No significant differences in the both bond distances and angles in each titanium complex were observed in the Cp analogue (4), whereas slight differences in both the distances and the angles were observed in the $\mathrm{Cp}^{*}$ analogue (5) and the 1,2,4-Me $\mathrm{C}_{3} \mathrm{C}_{5} \mathrm{H}_{2}$ analogue (7), probably due to a steric bulk. ${ }^{17}$ It seems likely that the $\mathrm{Ti}-\mathrm{Cl}$ bond distances in the $\mathrm{Cp}^{*}$ analogue $[5,2.2546(15)-2.2702(14) \AA]$ is slightly longer than those in the Cp $[4,2.2361(16), 2.2649(19) \AA]$ and the 1,2,4$\mathrm{Me}_{3} \mathrm{C}_{5} \mathrm{H}_{2}$ analogues $[7,2.2376(11)-2.2679(10) \AA] ;{ }^{17}$ the Ti-O bond distances in $5[1.789(3)-1.792(3) \AA]$ are slightly longer than those in 4 [1.774(3) $\AA$ ] but within the range of those in 7 [1.779(2)-1.797(2) $\AA$ ]. The Ti-O-C(3) in phenyl angles increased in the order: $157.6(2)^{\circ}\left(4, \mathrm{Cp}^{\prime}=\mathrm{Cp}\right)<163.0(2)-166.7(2)(7,1,2,4$ $\left.\mathrm{Me}_{3} \mathrm{C}_{5} \mathrm{H}_{2}\right)<167.9(3)-169.8(3)^{\circ}\left(5, \mathrm{Cp}^{*}\right)$. Moreover, the Ti-O-C bond angle in 5 is larger than that in $\mathrm{Cp}^{*} \mathrm{TiCl}_{2}\left(\mathrm{O}-2,6-{ }^{t} \mathrm{Bu}_{2} \mathrm{C}_{6} \mathrm{H}_{3}\right)$ $\left[155.5(2)^{\circ}\right]{ }^{14 c}$ probably due to less steric bulk. Since the observed difference in the $\mathrm{Ti}-\mathrm{O}-\mathrm{C}$ bond angle reflects the degree of $\mathrm{O}-\mathrm{Ti} \pi$-donation, this may explain the observed difference in the $\mathrm{Cp}^{*}$ analogue (5) especially compared to the $\mathrm{Cp}$ analogue (4). It also seems likely that both the $\mathrm{C}(1)-\mathrm{N}-\mathrm{C}(1)$ [or $\mathrm{C}(1)-\mathrm{N}-\mathrm{C}(26), \mathrm{C}(1)-\mathrm{N}-\mathrm{C}(24)]$ and $\mathrm{N}-\mathrm{C}(1)-\mathrm{C}(2)$ angles are slightly influenced by the cyclopentadienyl fragment (Table 1). As observed in the mononuclear half-titanocenes, ${ }^{10 i, 14}$ it was thus revealed that these bond distances and angles are influenced by the ligand substituent.

Fig. 3 shows ORTEP drawings for the binuclear complexes, $\left[\mathrm{Cp}^{\prime} \mathrm{TiCl}_{2}\left\{\left(\mathrm{O}-2,4-\mathrm{Me}_{2} \mathrm{C}_{6} \mathrm{H}_{2}\right)-6-\mathrm{CH}_{2}\right\}\right]\left[\mathrm{Cp}^{\prime} \mathrm{TiCl}\left\{\left(\mathrm{O}-2,4-\mathrm{Me}_{2} \mathrm{C}_{6} \mathrm{H}_{2}\right)-6-\right.\right.$ $\left.\left.\mathrm{CH}_{2}\right\}_{2}\right] \mathrm{N}\left[\mathrm{Cp}^{\prime}=\mathrm{Cp}^{*}(2), 1,2,4-\mathrm{Me}_{3} \mathrm{C}_{5} \mathrm{H}_{2}(3)\right]$, determined by X-ray crystallography. These complexes fold a distorted tetrahedral geometry around each titanium metal center. In the $\mathrm{Cp}^{*}$ analogue (2), the $\mathrm{Ti}(1)-\mathrm{Cl}(1), \mathrm{Ti}(1)-\mathrm{Cl}(2), \mathrm{Ti}(1)-\mathrm{O}(1)$ bond distances [monophenoxide, 2.2830(16), 2.2787(16), 1.776(3) ̊, respectively] are shorter than those in the bis(phenoxide) [Ti(2)$\mathrm{Cl}(3), \operatorname{Ti}(2)-\mathrm{O}(2), \mathrm{Ti}(2)-\mathrm{O}(3): 2.3140(15), 1.804(3), 1.806(3) \AA$, respectively], whereas there were no significant differences in the Ti-O-C (in phenyl) angles were observed [ $\mathrm{Ti}(1)-\mathrm{O}(1)-\mathrm{C}(3)$, $\mathrm{Ti}(2)-\mathrm{O}(2)-\mathrm{C}(22), \mathrm{Ti}(2)-\mathrm{O}(3)-\mathrm{C}(31): 172.4(3), 173.9(3), 174.0(3)^{\circ}$, respectively]. Therefore, the observed difference in the bond distances would be due to degree of $\pi$-donation from oxygen to 

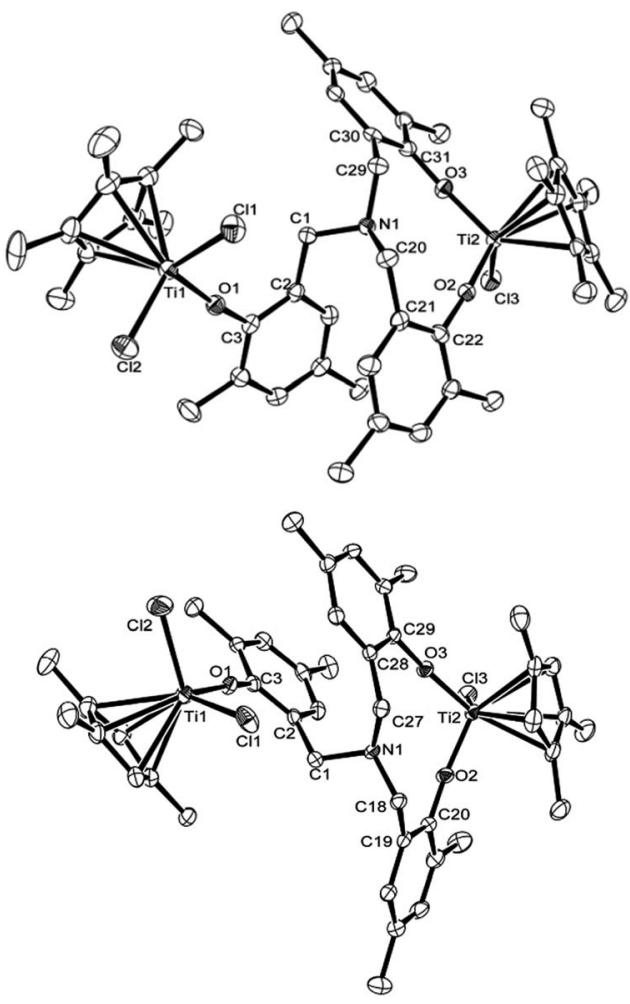

Fig. 3 ORTEP drawings for $\left[\mathrm{Cp}^{\prime} \operatorname{TiCl}_{2}\left\{\left(\mathrm{O}-2,4-\mathrm{Me}_{2} \mathrm{C}_{6} \mathrm{H}_{2}\right)-6-\mathrm{CH}_{2}\right\}\right]$ $\left[\mathrm{Cp}^{\prime} \mathrm{TiCl}\left\{\left(\mathrm{O}-2,4-\mathrm{Me}_{2} \mathrm{C}_{6} \mathrm{H}_{2}\right)-6-\mathrm{CH}_{2}\right\}_{2}\right] \mathrm{N} \quad\left[\mathrm{Cp}^{\prime}=\mathrm{Cp} *\right.$ (2, left), 1,2,4$\mathrm{Me}_{3} \mathrm{C}_{5} \mathrm{H}_{2}$ (3, right)]. Thermal ellipsoids are drawn at the $50 \%$ probability level, and $\mathrm{H}$ atoms are omitted for clarity. ${ }^{17}$ Selected bond distances ( $\AA$ ) and angles $\left({ }^{\circ}\right)$ in 2: $\mathrm{Ti}(1)-\mathrm{Cl}(1) 2.2830(16), \mathrm{Ti}(1)-\mathrm{Cl}(2) 2.2787(16), \mathrm{Ti}(1)-$ $\mathrm{O}(1)$ 1.776(3), $\mathrm{Ti}(2)-\mathrm{Cl}(3) 2.3140(15), \mathrm{Ti}(2)-\mathrm{O}(2)$ 1.804(3), $\mathrm{Ti}(2)-\mathrm{O}(3)$ 1.806(3), N(1)-C(1) 1.461(5), N(1)-C(20) 1.471(5), N(1)-C(29) 1.474(5) A; $\mathrm{Cl}(1)-\mathrm{Ti}(1)-\mathrm{Cl}(2)$ 103.17(5), $\mathrm{Cl}(1)-\mathrm{Ti}(1)-\mathrm{O}(1)$ 102.65(10), Cl(2)-Ti(1)$\mathrm{O}(1) \quad 102.46(10), \quad \mathrm{Cl}(3)-\mathrm{Ti}(2)-\mathrm{O}(2) \quad 100.78(10), \quad \mathrm{Cl}(3)-\mathrm{Ti}(2)-\mathrm{O}(3)$ 100.50(11), O(2)-Ti(2)-O(3) 108.14(12), Ti(1)-O(1)-C(3) 172.4(3), Ti(2)$\mathrm{O}(2)-\mathrm{C}(22) \quad 173.9(3), \quad \mathrm{Ti}(2)-\mathrm{O}(3)-\mathrm{C}(31) \quad 174.0(3), \quad \mathrm{C}(1)-\mathrm{N}(1)-\mathrm{C}(20)$ 112.2(3), $C(1)-N(1)-C(29) 110.3(3), C(20)-N(1)-C(29) 110.0(3), N(1)-$ $C(1)-C(2)$ 113.5(3), $\quad N(1)-C(20)-C(21)$ 113.8(3), $\quad N(1)-C(29)-C(30)$ $112.9(3)^{\circ}$. Selected bond distances $(\AA)$ and angles $\left(^{\circ}\right)$ in 3 : $\mathrm{Ti}(1)-\mathrm{Cl}(1)$ 2.2703(11), $\mathrm{Ti}(1)-\mathrm{Cl}(2) \quad 2.2655(11), \quad \mathrm{Ti}(1)-\mathrm{O}(1)$ 1.771(2), $\mathrm{Ti}(2)-\mathrm{Cl}(3)$ 2.3046(13), $\mathrm{Ti}(2)-\mathrm{O}(2) 1.802(2), \mathrm{Ti}(2)-\mathrm{O}(3)$ 1.793(2), N(1)-C(1) 1.472(4), $\mathrm{N}(1)-\mathrm{C}(18) 1.460(4), \mathrm{N}(1)-\mathrm{C}(27) 1.463(5) \AA ; \mathrm{Cl}(1)-\mathrm{Ti}(1)-\mathrm{Cl}(2) 101.44(5)$, $\mathrm{Cl}(1)-\mathrm{Ti}(1)-\mathrm{O}(1)$ 101.03(8), $\mathrm{Cl}(2)-\mathrm{Ti}(1)-\mathrm{O}(1)$ 104.74(8), $\mathrm{Cl}(3)-\mathrm{Ti}(2)-\mathrm{O}(2)$ 100.36(10), $\mathrm{Cl}(3)-\mathrm{Ti}(2)-\mathrm{O}(3)$ 102.06(9), O(2)-Ti(2)-O(3) 106.52(10), $\mathrm{Ti}(1)-\mathrm{O}(1)-\mathrm{C}(3)$ 167.6(2), $\mathrm{Ti}(2)-\mathrm{O}(2)-\mathrm{C}(20) 170.0(3), \mathrm{Ti}(2)-\mathrm{O}(3)-\mathrm{C}(29)$ 168.4(3), $C(1)-N(1)-C(18) 111.8(2), C(1)-N(1)-C(27) 112.8(2), C(18)-$ $N(1)-C(27) 110.6(3), N(1)-C(1)-C(2) 112.3(2), N(1)-C(18)-C(19) 114.1(3)$, $\mathrm{N}(1)-\mathrm{C}(27)-\mathrm{C}(28) 114.5(3)^{\circ}$.

titanium. The $\mathrm{C}(1)-\mathrm{N}-\mathrm{C}(20)$ bond angle $\left[112.2(3)^{\circ}\right]$ was rather larger than those in the others $[\mathrm{C}(1)-\mathrm{N}-\mathrm{C}(29), \mathrm{C}(20)-\mathrm{N}-\mathrm{C}(29)$ : $\left.110.3(3), 110.0(3)^{\circ}\right]$, whereas no significant differences were observed in $\mathrm{N}-\mathrm{C}(1)-\mathrm{C}(2), \mathrm{N}-\mathrm{C}(20)-\mathrm{C}(21)$, and $\mathrm{N}-\mathrm{C}(29)-\mathrm{C}(30)$ bond angles [113.5(5), 113.8(3), 112.9(3) ${ }^{\circ}$, respectively].

Structure in the $1,2,4-\mathrm{Me}_{3} \mathrm{C}_{5} \mathrm{H}_{2}$ analogue (3) is similar to that in the $\mathrm{Cp}^{*}$ analogue (2); the $\mathrm{Ti}(1)-\mathrm{Cl}(1)$, $\mathrm{Ti}(1)-\mathrm{Cl}(2), \mathrm{Ti}(1)-\mathrm{O}(1)$ bond distances [monophenoxide, 2.2703(11), 2.2655(11), 1.771(2) ^, respectively] are shorter than those in the bis(phenoxide) [ $\mathrm{Ti}(2)-\mathrm{Cl}(3), \operatorname{Ti}(2)-\mathrm{O}(2), \mathrm{Ti}(2)-\mathrm{O}(3): 2.3046(13)$, 1.802(2), 1.793(2) $\AA$, respectively], whereas no significant differences in the Ti-O-C (in phenyl) bond angles were observed [ $\mathrm{Ti}(1)-\mathrm{O}(1)-\mathrm{C}(3), \mathrm{Ti}(2)-\mathrm{O}(2)-\mathrm{C}(20), \mathrm{Ti}(2)-\mathrm{O}(3)-\mathrm{C}(29)$ : 167.6(2), $170.3(3), 168.4(3)^{\circ}$, respectively]. The Ti-O-C bond angles in the $\mathrm{Cp}^{*}$ analogue $\left[2: 172.4(3)-174.0(3)^{\circ}\right]$ were larger than those in the 1,2,4- $\mathrm{Me}_{3} \mathrm{C}_{5} \mathrm{H}_{2}$ analogue [3: 167.6(2)-170.0(3) ${ }^{\circ}$.

As shown in Scheme 4, [Cp*TiMe $2\left\{\left(\mathrm{O}-2,4-\mathrm{Me}_{2} \mathrm{C}_{6} \mathrm{H}_{2}\right)-6\right.$ $\left.\left.\mathrm{CH}_{2}\right\}\right]_{3} \mathrm{~N}(8)$ could be prepared from Cp*TiMe 3 , prepared in situ by treating $\mathrm{Cp}^{*} \mathrm{TiCl}_{3}$ with MeLi in toluene, by reacting with $\left[\left(\mathrm{HO}-2,4-\mathrm{Me}_{2} \mathrm{C}_{6} \mathrm{H}_{2}\right)-6-\mathrm{CH}_{2}\right]_{3} \mathrm{~N}$, although, as described above, attempted isolation of the dichloride analogue afforded the bimetallic complex, [Cp*TiCl $\left.2\left\{\left(\mathrm{O}-2,4-\mathrm{Me}_{2} \mathrm{C}_{6} \mathrm{H}_{2}\right)-6-\mathrm{CH}_{2}\right\}\right]-$ [Cp*TiCl $\left.\left\{\left(\mathrm{O}-2,4-\mathrm{Me}_{2} \mathrm{C}_{6} \mathrm{H}_{2}\right)-6-\mathrm{CH}_{2}\right\}_{2}\right] \mathrm{N}$ (2). It was also revealed that the reaction of $\left[\mathrm{Cp}^{*} \mathrm{TiCl}_{2}\left\{\left(\mathrm{O}-2,4-{ }^{t}{ }^{-} \mathrm{Bu}_{2} \mathrm{C}_{6} \mathrm{H}_{2}\right)-6-\mathrm{CH}_{2}\right\}\right]_{3} \mathrm{~N}(5)$ with $\mathrm{MeMgBr}$ afforded the corresponding dimethyl complex (9), although the similar attempt for obtainment of 9 through onepot synthesis from $\mathrm{Cp}^{*} \mathrm{TiCl}_{3}$ (at $25{ }^{\circ} \mathrm{C}$ overnight) failed and recovered both $\mathrm{Cp}^{*} \mathrm{TiMe}_{3}$ and $\left[\left(\mathrm{HO}-2,4{ }^{-}{ }^{t} \mathrm{Bu}_{2} \mathrm{C}_{6} \mathrm{H}_{2}\right)-6-\mathrm{CH}_{2}\right]_{3} \mathrm{~N}$ (shown in the ESI $\dagger$ ). ${ }^{15}$ These complexes $(\mathbf{8}$ and $\mathbf{9}$ ) were identified by NMR spectra and elemental analysis, and the structure of $\mathbf{9}$ could be determined by X-ray crystallographic analysis (shown in Fig. 4).

Complex 9 folds a distorted tetrahedral geometry around each titanium, and no significant differences in $\mathrm{Ti}-\mathrm{O}$, Ti-C (in methyl) bond distances, $\mathrm{C}($ methyl)-Ti-C(methyl), Ti-O-C (in phenyl) angles etc. were observed in the three titanium complexes in 9. The Ti-O bond distances in 9 [1.8149(17)$1.8230(17) \AA]$ are longer than those in the dichloride analogue [5: 1.789(3)-1.792(3) $\AA]$, and Ti-O-C (in phenyl) bond angles in 9 $\left[165.28(15)-166.02(16)^{\circ}\right]$ are smaller than those in $5[167.9(3)-$ $\left.169.8(3)^{\circ}\right]$. Moreover, the bond angles formed by two methyl group and titanium in 9 [95.20(13)-96.79(12)] are smaller than those formed by two chloride and the titanium in 5 [101.11(5)101.85(6)]. ${ }^{17}$ These are observed trend between the dichloride and the dimethyl complex, exemplified by $\mathrm{Cp} * \mathrm{TiX}_{2}\left(\mathrm{O}^{\mathrm{i}}{ }^{\mathrm{P}} \mathrm{Pr}_{2} \mathrm{C}_{6} \mathrm{H}_{3}\right)$ [Ti-O, Ti-O-C (phenyl), X(1)-Ti-X(2): 1.772(3) $\AA$, 173.0(3) 103.4(5) $)^{\circ}$, respectively $(\mathrm{X}=\mathrm{Cl}) ; 1.790(2) \AA, 168.7^{\circ}, 99.8(1)^{\circ}$

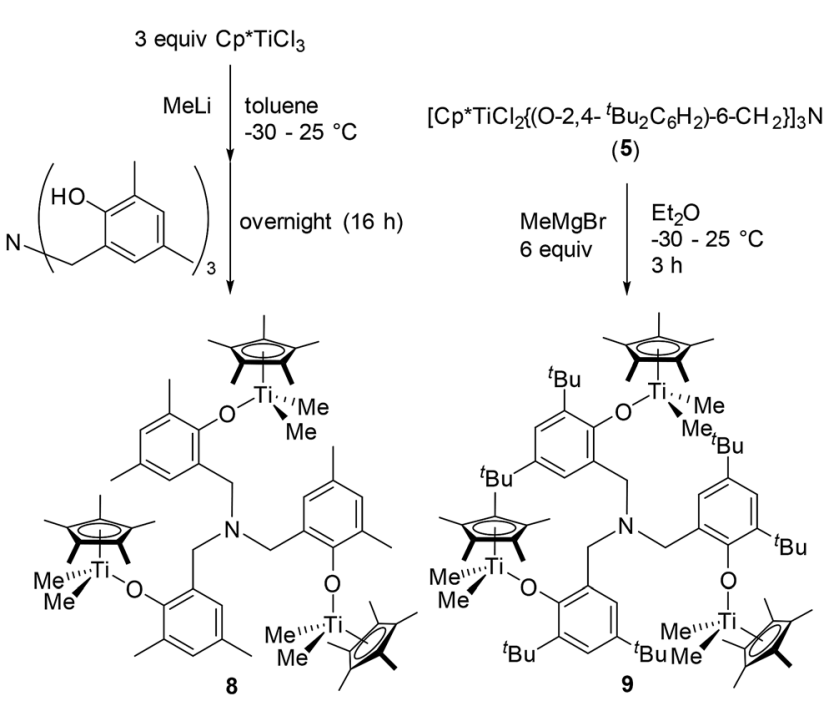

Scheme 4 Synthesis of $\left[\mathrm{Cp} * \mathrm{TiMe}_{2}\left\{\left(\mathrm{O}-2,4-\mathrm{R}_{2} \mathrm{C}_{6} \mathrm{H}_{2}\right)-6-\mathrm{CH}_{2}\right\}\right]_{3} \mathrm{~N}[\mathrm{R}=$ $\left.\mathrm{Me}(8),{ }^{t} \mathrm{Bu}(9)\right]$. 


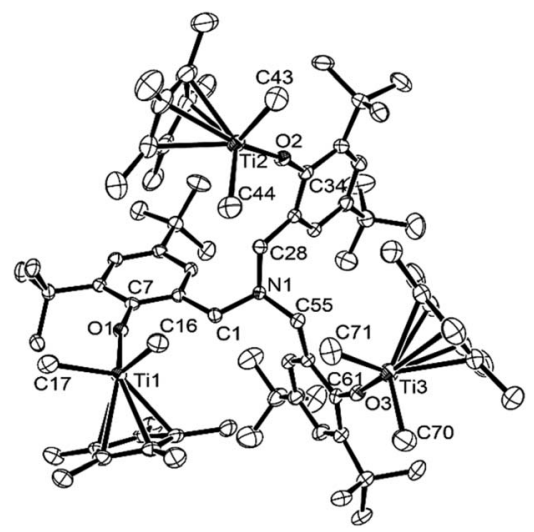

Fig. 4 ORTEP drawing for [Cp*TiMe $\left.2\left\{\left(\mathrm{O}-2,4-{ }^{t} \mathrm{Bu}_{2} \mathrm{C}_{6} \mathrm{H}_{2}\right)-6-\mathrm{CH}_{2}\right\}\right]_{3} \mathrm{~N}$ (9). Thermal ellipsoids are drawn at the $50 \%$ probability level, and $\mathrm{H}$ atoms are omitted for clarity. ${ }^{17}$ Selected bond distances $(\AA)$ : $\mathrm{Ti}(1)-\mathrm{O}(1)$ 1.8221(16), $\mathrm{Ti}(2)-\mathrm{O}(2)$ 1.8230(17), $\mathrm{Ti}(3)-\mathrm{O}(3)$ 1.8149(17), $\mathrm{Ti}(1)-\mathrm{C}(16)$ 2.122(2), Ti(1)-C(17) 2.133(3), Ti(2)-C(43) 2.122(3), Ti(2)-C(44) 2.136(3), $\mathrm{Ti}(3)-\mathrm{C}(70) 2.129(4), \mathrm{Ti}(3)-\mathrm{C}(71) 2.128(3), \mathrm{N}(1)-\mathrm{C}(1)$ 1.462(3), N(1)$C(28) 1.467(3), N(1)-C(55) 1.456(3)$. Selected bond angle $\left({ }^{\circ}\right)$ : $C(16)-$ $\mathrm{Ti}(1)-\mathrm{C}(17)$ 95.63(10), C(43)-Ti(2)-C(44) 96.79(12), C(70)-Ti(3)-C(71) 95.20(13), $\mathrm{Ti}(1)-\mathrm{O}(1)-\mathrm{C}(7)$ 165.63(15), $\mathrm{Ti}(2)-\mathrm{O}(2)-\mathrm{C}(34)$ 165.28(15), $\mathrm{Ti}(3)-\mathrm{O}(3)-\mathrm{C}(61) 166.02(16)$.

$(\mathrm{X}=\mathrm{Me})],{ }^{14 e}$ and rather small bond angles in 9, described above, compared to those in $\mathbf{5}$ would be explained due to a steric bulk (rather large methyl group compared to $\mathrm{Cl}$ ).

\section{Ethylene polymerisation by $\left[\mathrm{Cp}^{\prime} \mathrm{TiCl}_{2}\left\{\left(\mathrm{O}-2,4-\mathrm{R}_{2} \mathrm{C}_{6} \mathrm{H}_{2}\right)-6-\right.\right.$} $\left.\left.\mathrm{CH}_{2}\right\}\right]_{3} \mathbf{N}\left[\mathbf{R}=\mathrm{Me}, \mathrm{Cp}^{\prime}=\mathbf{C p}(1) ; \mathbf{R}={ }^{t} \mathbf{B u}, \mathbf{C p}^{\prime}=\mathbf{C p}(4), \mathbf{C p}^{*}\right.$ (5), ${ }^{t} \mathrm{BuC}_{5} \mathrm{H}_{4}$ (6), 1,2,4-Me ${ }_{3} \mathrm{C}_{5} \mathrm{H}_{2}$ (7)], [C ${ }^{\prime} \operatorname{TiCl}_{2}\left\{\left(\mathrm{O}-2,4-\mathrm{Me}_{2} \mathrm{C}_{6} \mathrm{H}_{2}\right)-6\right.$ $\left.\left.\mathrm{CH}_{2}\right\}\right]\left[\mathbf{C p}^{\prime} \mathbf{T i C l}\left\{\left(\mathrm{O}-2,4-\mathrm{Me}_{2} \mathrm{C}_{6} \mathrm{H}_{2}\right)-\mathbf{6}-\mathrm{CH}_{2}\right\}_{2}\right] \mathbf{N}\left[\mathrm{Cp}^{\prime}=\mathbf{C p}^{*}(2)\right.$, 1,2,4-Me $\left.\mathrm{MC}_{5} \mathrm{H}_{2}(3)\right]$, and $\left[\mathrm{Cp}^{*} \mathrm{TiMe}_{2}\left\{\left(\mathrm{O}-2,4-\mathrm{R}_{2} \mathrm{C}_{6} \mathrm{H}_{2}\right)-6-\mathrm{CH}_{2}\right\}\right]_{3} \mathrm{~N}$ $\left[\mathrm{R}=\mathrm{Me}(8),{ }^{t} \mathrm{Bu}(9)\right]$

Table 2 summarises results in ethylene polymerisation at $25{ }^{\circ} \mathrm{C}$ in toluene using $\left[\mathrm{Cp}^{\prime} \mathrm{TiCl}_{2}\left\{\left(\mathrm{O}-2,4-\mathrm{R}_{2} \mathrm{C}_{6} \mathrm{H}_{2}\right)-6-\mathrm{CH}_{2}\right\}\right]_{3} \mathrm{~N}[\mathrm{R}=\mathrm{Me}$, $\mathrm{Cp}^{\prime}=\mathrm{Cp}(\mathbf{1}) ; \mathrm{R}={ }^{t} \mathrm{Bu}, \mathrm{Cp}^{\prime}=\mathrm{Cp}(4), \mathrm{Cp}^{*}(5),{ }^{t} \mathrm{BuC}_{5} \mathrm{H}_{4}$ (6), 1,2,4$\mathrm{Me}_{3} \mathrm{C}_{5} \mathrm{H}_{2}$ (7)], $\left[\mathrm{Cp}^{\prime} \mathrm{TiCl}_{2}\left\{\left(\mathrm{O}-2,4-\mathrm{Me}_{2} \mathrm{C}_{6} \mathrm{H}_{2}\right)-6-\mathrm{CH}_{2}\right\}\right]\left[\mathrm{Cp}^{\prime} \mathrm{TiCl}\{(\mathrm{O}-\right.$ 2,4- $\left.\left.\left.\mathrm{Me}_{2} \mathrm{C}_{6} \mathrm{H}_{2}\right)-6-\mathrm{CH}_{2}\right\}_{2}\right] \mathrm{N}\left[\mathrm{Cp}^{\prime}=\mathrm{Cp}^{*}(2), 1,2,4-\mathrm{Me}_{3} \mathrm{C}_{5} \mathrm{H}_{2}(3)\right]$, and $\left[\mathrm{Cp}^{*} \mathrm{TiMe}_{2}\left\{\left(\mathrm{O}-2,4-\mathrm{R}_{2} \mathrm{C}_{6} \mathrm{H}_{2}\right)-6-\mathrm{CH}_{2}\right\}\right]_{3} \mathrm{~N}\left[\mathrm{R}=\mathrm{Me}(\mathbf{8}),{ }^{t} \mathrm{Bu}(\mathbf{9})\right]$ in the presence of methyl-aluminoxane (MAO) cocatalyst. MAO white solid, prepared by removing toluene and $\mathrm{AlMe}_{3}$ from the commercially available sample [TMAO, $9.5 \mathrm{wt} \%$ (Al) toluene solution, Tosoh Finechem Co.], was employed because use of this MAO was effective in the ethylene (co)polymerisation for obtainment of (co)polymers with uniform molecular weight distributions. ${ }^{\mathbf{1 0 , 1 4 b , c , f}}$

It turned out that the $\mathrm{Cp}$ analogues $(\mathbf{1}, \mathbf{4})$ exhibited low catalytic activities affording ultrahigh molecular weight polymers with uniform molecular weight distributions $\left(M_{\mathrm{n}}=2.02-\right.$ $3.58 \times 10^{6}, M_{\mathrm{w}} / M_{\mathrm{n}}=2.06-2.66$, runs $1,6-11$ and runs $\mathrm{S} 1$ in Table S1 in the ESI $\dagger) .{ }^{18}$ It also turned out that the activities at $25{ }^{\circ} \mathrm{C}$ by the $1,2,4-\mathrm{Me}_{3} \mathrm{C}_{5} \mathrm{H}_{2}$ analogues ( 3 and 7 ) and the ${ }^{t} \mathrm{BuC}_{5} \mathrm{H}_{4}$ analogue (6) were low and the resultant polymers prepared by 3 and 7 possessed bimodal molecular weight distributions (runs $5,14,15$, runs S3, S6 and S7 $\dagger$ ), although slight improvement in the activity was observed by the bimetallic complex (3) compared to 1 . In contrast, it was revealed that the bimetallic $\mathrm{Cp}^{*}$ analogue (2) and the $\mathrm{Cp}^{*}$-dimethyl analogues $(\mathbf{8}, \mathbf{9})$ exhibited higher catalytic activities (9060-16 $800 \mathrm{~kg}$ PE per mol Ti per h, runs 2-4, 16-18) than the others, whereas the activity by the related $\mathrm{Cp}^{*}$-dichloride analogue (5) was low (384-428 kg PE per mol Ti per $\mathrm{h}$, runs $12, \mathrm{~S} 4 \dagger)$. The resultant polymers prepared by $\mathbf{8}$ and $\mathbf{9}$ possessed ultrahigh molecular weights with unimodal molecular weight distributions $\left(M_{\mathrm{n}}=1.21-3.68 \times\right.$ $10^{6}, M_{\mathrm{w}} / M_{\mathrm{n}}=2.16-3.16$, runs $16-18$, runs S9-S11 in the ESI $\left.\dagger\right){ }^{18}$ whereas the resultant polymers prepared by 2 possessed a mixture of ultrahigh and low molecular weights (runs 2-4, $\mathrm{S} 2 \dagger)$ which might suggest a presence of two catalytically active species in situ. The observed polymerisation results are reproducible as shown in runs 6-11 as well as shown in the ESI. $\dagger^{\mathbf{1 8}}$

It was revealed that the activities (on the basis of polymer yields) by $\left[\mathrm{Cp}^{\prime} \mathrm{TiCl}_{2}\left\{\left(\mathrm{O}-2,4{ }^{-}{ }^{t} \mathrm{Bu}_{2} \mathrm{C}_{6} \mathrm{H}_{2}\right)-6-\mathrm{CH}_{2}\right\}\right]_{3} \mathrm{~N}\left[\mathrm{Cp}^{\prime}=\mathrm{Cp}(4)\right.$, $\left.\mathrm{Cp}^{*}(5),{ }^{t} \mathrm{BuC}_{5} \mathrm{H}_{4}(6), 1,2,4-\mathrm{Me}_{3} \mathrm{C}_{5} \mathrm{H}_{2}(7)\right]$ increased at $50{ }^{\circ} \mathrm{C}$, and the resultant polymers by both the $\mathrm{Cp}$ analogue (4) and ${ }^{t} \mathrm{BuC}_{5} \mathrm{H}_{4}$ analogue (6) possessed ultrahigh molecular weights with unimodal molecular weight distributions $\left(M_{\mathrm{n}}=2.08-2.28 \times 10^{6}\right.$, $M_{\mathrm{w}} / M_{\mathrm{n}}=2.04-2.48$, runs $19,20, \mathrm{~S} 12$, S13, Table 3 and ESI $\left.\dagger\right) .{ }^{18}$ Although notable improvement in the activity was observed when the polymerisation by 5 was conducted at $50{ }^{\circ} \mathrm{C}$ (run 24 ), the catalyst was short lived at $80{ }^{\circ} \mathrm{C}$ (runs 25,26 ) and the activity decreased at $100{ }^{\circ} \mathrm{C}$ (run 27).$^{18}$ Moreover, the activity by 2 decreased upon increasing the polymerisation temperature (runs 22 and 23). ${ }^{18}$ The dimethyl analogues $(\mathbf{8}, 9)$ also showed the similar trends, and the activities decreased at $50{ }^{\circ} \mathrm{C}$ probably due to partial decomposition of the catalytically active species (runs 16, 17, 28-31, S21-S24†). ${ }^{18}$

Ethylene polymerisations using the mononuclear analogues, $\mathrm{CpTiCl}_{2}\left(\mathrm{O}-2-\mathrm{R}-4,6-\mathrm{Me}_{2} \mathrm{C}_{6} \mathrm{H}_{2}\right) \quad\left[\mathrm{R}=\mathrm{Me}(\mathbf{1 0}),{ }^{t} \mathrm{Bu}\right.$ (11)], and $\mathrm{Cp}^{*} \mathrm{TiCl}_{2}\left(\mathrm{O}-2-\mathrm{R}-4,6-\mathrm{Me}_{2} \mathrm{C}_{6} \mathrm{H}_{2}\right)\left[\mathrm{R}=\mathrm{Me}(\mathbf{1 2}),{ }^{t} \mathrm{Bu}(13)\right],{ }^{14 b, c}$ were also conducted under the same conditions for comparison. Complexes 10 and 11 were prepared according the analogous procedure for synthesis of the Cp-aryloxo analogues (shown in the Experimental section). ${ }^{\mathbf{1 0 i , 1 4 b , c}}$ The results are summarised in Table 4 . The selected results by the trinuclear analogues, $\left[\mathrm{Cp}^{\prime} \mathrm{TiCl}_{2}\left\{\left(\mathrm{O}-2,4-\mathrm{R}_{2} \mathrm{C}_{6} \mathrm{H}_{2}\right)-6-\mathrm{CH}_{2}\right\}\right]_{3} \mathrm{~N}\left[\mathrm{R}=\mathrm{Me}, \mathrm{Cp}^{\prime}=\mathrm{Cp}(\mathbf{1}) ;\right.$ $\left.\mathrm{R}={ }^{t} \mathrm{Bu}, \mathrm{Cp}^{\prime}=\mathrm{Cp}(4), \mathrm{Cp}^{*}(5)\right]$ and $\left[\mathrm{Cp}^{*} \mathrm{TiMe}_{2}\left\{\left(\mathrm{O}-2,4-\mathrm{R}_{2} \mathrm{C}_{6} \mathrm{H}_{2}\right)-6-\right.\right.$ $\left.\left.\mathrm{CH}_{2}\right\}\right]_{3} \mathrm{~N}\left[\mathrm{R}=\mathrm{Me}(\mathbf{8}),{ }^{t} \mathrm{Bu}(\mathbf{9})\right]$, and bimetallic [Cp*TiCl $2\{(\mathrm{O}-2,4-$ $\left.\left.\left.\mathrm{Me}_{2} \mathrm{C}_{6} \mathrm{H}_{2}\right)-6-\mathrm{CH}_{2}\right\}\right]\left[\mathrm{Cp} * \mathrm{TiCl}\left\{\left(\mathrm{O}-2,4-\mathrm{Me}_{2} \mathrm{C}_{6} \mathrm{H}_{2}\right)-6-\mathrm{CH}_{2}\right\}_{2}\right] \mathrm{N}$ (2) are also placed for comparison.

It turned out that the activity by the $\mathrm{Cp}$ analogue, $\left[\mathrm{CpTiCl}_{2}\left\{\left(\mathrm{O}-2,4-\mathrm{Me}_{2} \mathrm{C}_{6} \mathrm{H}_{2}\right)-6-\mathrm{CH}_{2}\right\}\right]_{3} \mathrm{~N}(\mathbf{1})$, was lower than that by $\mathrm{CpTiCl}_{2}\left(\mathrm{O}-2,4,6-\mathrm{Me}_{3} \mathrm{C}_{6} \mathrm{H}_{2}\right)(\mathbf{1 0})$ (runs 1, 32), ${ }^{18}$ probably due to disproportionation of 1 (generating $\mathrm{CpTiCl}_{3}$ exhibiting negligible activity $)^{14 c}$ in the toluene solution as shown in Fig. 1. It also turned out that the activities by $\mathbf{4}$ were lower than those by the related mononuclear analogue (11) [runs 8, 19 (by 4) vs. runs 33, 34 (by 11)]. However, the resultant polymers prepared by 4 possessed unimodal molecular weight distributions suggesting a possibility that the polymerisation proceeded with uniform catalytically active species, whereas the resultant polymers prepared by $\mathbf{1 1}$ possessed the broad distributions (strongly 
Table 2 Ethylene polymerisation by $\left[\mathrm{Cp}^{\prime} \mathrm{TiCl}_{2}\left\{\left(\mathrm{O}-2,4-\mathrm{R}_{2} \mathrm{C}_{6} \mathrm{H}_{2}\right)-6-\mathrm{CH}_{2}\right\}\right]_{3} \mathrm{~N}\left[\mathrm{R}=\mathrm{Me}, \mathrm{Cp}^{\prime}=\mathrm{Cp}(1) ; \mathrm{R}={ }^{t} \mathrm{Bu}, \mathrm{Cp}{ }^{\prime}=\mathrm{Cp}(4), \mathrm{Cp} *(5),{ }^{t} \mathrm{BuC}{ }_{5} \mathrm{H}_{4}(6), 1,2,4-\right.$ $\left.\mathrm{Me}_{3} \mathrm{C}_{5} \mathrm{H}_{2}(7)\right],\left[\mathrm{Cp}^{\prime} \mathrm{TiCl}_{2}\left\{\left(\mathrm{O}-2,4-\mathrm{Me}_{2} \mathrm{C}_{6} \mathrm{H}_{2}\right)-6-\mathrm{CH}_{2}\right\}\right]\left[\mathrm{Cp} \mathrm{T}^{\prime} \mathrm{TiCl}\left\{\left(\mathrm{O}-2,4-\mathrm{Me}_{2} \mathrm{C}_{6} \mathrm{H}_{2}\right)-6-\mathrm{CH}_{2}\right\}_{2}\right] \mathrm{N}\left[\mathrm{Cp} p^{\prime}=\mathrm{Cp} *(2), 1,2,4-\mathrm{Me}_{3} \mathrm{C}_{5} \mathrm{H}_{2}(3)\right]$, and $\left[\mathrm{Cp} * \mathrm{TiMe}{ }_{2}\{(\mathrm{O}-\right.$ $\left.\left.\left.2,4-\mathrm{R}_{2} \mathrm{C}_{6} \mathrm{H}_{2}\right)-6-\mathrm{CH}_{2}\right\}\right]_{3} \mathrm{~N}\left[\mathrm{R}=\mathrm{Me}(8),{ }^{t} \mathrm{Bu}(9)\right]$ in the presence of MAO cocatalyst (ethylene 4 atm, $\left.25^{\circ} \mathrm{C}\right)^{a}$

\begin{tabular}{|c|c|c|c|c|c|c|c|}
\hline Run & Catalyst ( $\mu \mathrm{mol})$ & $\mathrm{MAO} / \mathrm{mmol}$ & Time/min & Polymer/mg & Activity $^{b}$ & $M_{\mathrm{n}}^{c} \times 10^{-4}$ & $M_{\mathrm{w}} / M_{\mathrm{n}}^{c}$ \\
\hline 1 & $1(0.50)$ & 3.0 & 10 & 80 & 320 & 341 & 2.13 \\
\hline 2 & $2(0.03)$ & 3.0 & 10 & 107 & 10700 & $309,3.91$ & $2.11,1.95$ \\
\hline 3 & $2(0.03)$ & 3.0 & 5 & 78 & 15600 & $368,3.09$ & $2.67,2.19$ \\
\hline 4 & $2(0.03)$ & 3.0 & 5 & 75 & 15000 & $300,1.93$ & $2.29,2.58$ \\
\hline 5 & $3(0.30)$ & 3.0 & 10 & 116 & 1160 & $368,0.96$ & $1.72,1.82$ \\
\hline 6 & $4(0.50)$ & 2.0 & 10 & 120 & 480 & 220 & 2.13 \\
\hline 7 & $4(0.50)$ & 2.0 & 10 & 124 & 496 & 239 & 2.21 \\
\hline 8 & $4(0.50)$ & 3.0 & 10 & 186 & 744 & 204 & 2.44 \\
\hline 9 & $4(0.50)$ & 3.0 & 10 & 180 & 720 & 202 & 2.48 \\
\hline 10 & $4(0.50)$ & 4.0 & 10 & 140 & 560 & 238 & 2.64 \\
\hline 11 & $4(0.50)$ & 4.0 & 10 & 136 & 544 & 232 & 2.66 \\
\hline 12 & $5(0.50)$ & 3.0 & 10 & 107 & 428 & 172 & 2.90 \\
\hline 13 & $6(0.50)$ & 3.0 & 10 & 44 & 176 & 277 & 2.26 \\
\hline 14 & $7(0.25)$ & 3.0 & 10 & 75 & 600 & $93.1,1.12$ & $3.95,2.11$ \\
\hline 15 & $7(0.25)$ & 3.0 & 5 & 26 & 416 & $238,0.97$ & $2.75,2.05$ \\
\hline 16 & $8(0.01)$ & 3.0 & 10 & 84 & 16800 & 214 & 2.20 \\
\hline 17 & $9(0.10)$ & 3.0 & 10 & 453 & 9060 & 354 & 2.24 \\
\hline 18 & $9(0.01)$ & 3.0 & 10 & 58 & 11600 & 128 & 3.04 \\
\hline
\end{tabular}

${ }^{a}$ Conditions: toluene total $30 \mathrm{~mL}$, d-MAO (prepared by removing toluene and $\mathrm{AlMe}_{3}$ from the ordinary MAO). ${ }^{b}$ Activity in kg PE per mol Ti per h. ${ }^{c}$ GPC data in $o$-dichlorobenzene $v s$. polystyrene standards.

Table 3 Effect of polymerisation temperature in ethylene polymerisation by $\left[\mathrm{Cp}^{2} \mathrm{TiCl}_{2}\left\{\left(\mathrm{O}-2,4-\mathrm{Me}_{2} \mathrm{C}_{6} \mathrm{H}_{2}\right)-6-\mathrm{CH}_{2}\right\}\right]\left[\mathrm{Cp} * \mathrm{TiCl}_{2}\left(\mathrm{O}-2,4-\mathrm{Me} \mathrm{C}_{6} \mathrm{H}_{2}\right)-6-\right.$ $\left.\left.\mathrm{CH}_{2}\right\}_{2}\right] \mathrm{N}(2),\left[\mathrm{Cp}^{\prime} \mathrm{TiCl}_{2}\left\{\left(\mathrm{O}-2,4-{ }^{t} \mathrm{Bu}_{2} \mathrm{C}_{6} \mathrm{H}_{2}\right)-6-\mathrm{CH}_{2}\right\}\right]_{3} \mathrm{~N}\left[\mathrm{Cp}{ }^{\prime}=\mathrm{Cp}(4), \mathrm{Cp} *(5),{ }^{t} \mathrm{BuC}_{5} \mathrm{H}_{4}(6), 1,2,4-\mathrm{Me}_{3} \mathrm{C}_{5} \mathrm{H}_{2}(7)\right]$, and $\left[\mathrm{Cp}^{*} \mathrm{TiMe} 2\left\{\left(\mathrm{O}-2,4-\mathrm{R}_{2} \mathrm{C}_{6} \mathrm{H}_{2}\right)-6-\right.\right.$ $\left.\left.\mathrm{CH}_{2}\right\}\right]_{3} \mathrm{~N}\left[\mathrm{R}=\mathrm{Me}(8),{ }^{t} \mathrm{Bu}(9)\right]$ in the presence of MAO cocatalyst ${ }^{a}$

\begin{tabular}{|c|c|c|c|c|c|c|c|}
\hline Run & Catalyst ( $\mu \mathrm{mol})$ & Temp. $/{ }^{\circ} \mathrm{C}$ & Time/min & Polymer/mg & Activity $^{b}$ & $M_{\mathrm{n}}^{c} \times 10^{-4}$ & $M_{\mathrm{w}} / M_{\mathrm{n}}{ }^{c}$ \\
\hline 8 & $4(0.50)$ & 25 & 10 & 186 & 744 & 204 & 2.44 \\
\hline 19 & $4(0.10)$ & 50 & 10 & 74 & 1480 & 215 & 2.04 \\
\hline 20 & $6(0.30)$ & 50 & 10 & 58 & 387 & 226 & 2.48 \\
\hline 14 & $7(0.25)$ & 25 & 10 & 75 & 600 & $93.1,1.12$ & $3.95,2.11$ \\
\hline 21 & $7(0.10)$ & 50 & 10 & 43 & 860 & $220,0.67$ & $2.15,1.62$ \\
\hline 23 & $2(0.05)$ & 80 & 10 & 65 & 3900 & $173,0.95$ & $1.47,1.81$ \\
\hline 12 & $5(0.50)$ & 25 & 10 & 107 & 428 & 172 & 2.90 \\
\hline 24 & $5(0.10)$ & 50 & 10 & 158 & 3160 & 113 & 2.85 \\
\hline 25 & $5(0.10)$ & 80 & 10 & 150 & 3000 & $26.4,0.83$ & $3.08,1.63$ \\
\hline 26 & $5(0.10)$ & 80 & 5 & 121 & 4840 & $37.7,0.88$ & $4.85,1.64$ \\
\hline 27 & $5(0.10)$ & 100 & 10 & 68 & 1360 & $112,0.61$ & $1.92,1.68$ \\
\hline 17 & $9(0.10)$ & 25 & 10 & 453 & 9060 & 354 & 2.24 \\
\hline 18 & $9(0.01)$ & 25 & 10 & 58 & 11600 & 128 & 3.04 \\
\hline 31 & $9(0.05)$ & 50 & 10 & 107 & 4280 & $126,2.44$ & $3.94,1.53$ \\
\hline
\end{tabular}

${ }^{a}$ Conditions: toluene total $30 \mathrm{~mL}$, d-MAO $3.0 \mathrm{mmol}$, ethylene $4 \mathrm{~atm} .{ }^{b}$ Activity in $\mathrm{kg}$ PE per mol Ti per h. ${ }^{c}$ GPC data in $o$-dichlorobenzene $v s$. polystyrene standards.

suggesting a possibility that several catalytically active species were present in situ).

Note that the activities by the $\mathrm{Cp}^{*}$ trinuclear analogue, $\left[\mathrm{Cp}^{*} \mathrm{TiMe}_{2}\left\{\left(\mathrm{O}-2,4-\mathrm{Me}_{2} \mathrm{C}_{6} \mathrm{H}_{2}\right)-6-\mathrm{CH}_{2}\right\}\right]_{3} \mathrm{~N}(8)$ showed higher catalytic activities than the related mononuclear analogue, $\mathrm{Cp}^{*} \mathrm{TiCl}_{2}\left(\mathrm{O}-2,4,6-\mathrm{Me}_{3} \mathrm{C}_{6} \mathrm{H}_{2}\right)$ (12) [runs 16, 28 (by 8) vs. runs 35,
36 (by 12)]. ${ }^{18}$ The activities by 2 and 8 were higher than those by Cp* ${ }^{*} \mathrm{TiCl}_{2}\left(\mathrm{O}-2-{ }^{t} \mathrm{Bu}-4,6-\mathrm{Me}_{2} \mathrm{C}_{6} \mathrm{H}_{2}\right)(13)$ conducted under the same conditions (runs 2, 16, $28 v s$. runs 37, 38). Although the activity by $\left[\mathrm{Cp}^{*} \mathrm{TiCl}_{2}\left\{\left(\mathrm{O}-2,4-{ }^{t} \mathrm{Bu}_{2} \mathrm{C}_{6} \mathrm{H}_{2}\right)-6-\mathrm{CH}_{2}\right\}\right]_{3} \mathrm{~N}(5)$ at $25{ }^{\circ} \mathrm{C}$ was low, the activity increased at $50{ }^{\circ} \mathrm{C}$ (runs 12,24 ), whereas no significant increase in the activity by 13 were observed at $50{ }^{\circ} \mathrm{C}$ (runs 
Table 4 Summary of results in ethylene polymerisation by $\left[\mathrm{Cp}^{\prime} \mathrm{TiCl}_{2}\left\{\left(\mathrm{O}-2,4-\mathrm{R}_{2} \mathrm{C}_{6} \mathrm{H}_{2}\right)-6-\mathrm{CH}_{2}\right\}\right]_{3} \mathrm{~N}\left[\mathrm{R}=\mathrm{Me}, \mathrm{Cp}{ }^{\prime}=\mathrm{Cp}(1) ; \mathrm{R}={ }^{t} \mathrm{Bu}, \mathrm{Cp}{ }^{\prime}=\mathrm{Cp}(4), \mathrm{Cp} *\right.$ (5)], $\left[\mathrm{Cp} * \mathrm{TiCl}_{2}\left\{\left(\mathrm{O}-2,4-\mathrm{Me}_{2} \mathrm{C}_{6} \mathrm{H}_{2}\right)-6-\mathrm{CH}_{2}\right\}\right]\left[\mathrm{Cp} * \mathrm{TiCl}\left\{\left(\mathrm{O}-2,4-\mathrm{Me}_{2} \mathrm{C}_{6} \mathrm{H}_{2}\right)-6-\mathrm{CH}_{2}\right\}_{2}\right] \mathrm{N}(2)$, and $\left[\mathrm{Cp} * \mathrm{TiMe}_{2}\left\{\left(\mathrm{O}-2,4-\mathrm{R}_{2} \mathrm{C}_{6} \mathrm{H}_{2}\right)-6-\mathrm{CH} \mathrm{H}_{2}\right\}\right]_{3} \mathrm{~N}\left[\mathrm{R}=\mathrm{Me}(8),{ }^{t} \mathrm{Bu}\right.$ (9)], and $\mathrm{Cp}^{\prime} \mathrm{TiCl}_{2}\left(\mathrm{O}-2-\mathrm{R}-4,6-\mathrm{Me}_{2} \mathrm{C}_{6} \mathrm{H}_{2}\right)\left[C \mathrm{C}^{\prime}=\mathrm{Cp}, \mathrm{R}=\mathrm{Me}(10),{ }^{t} \mathrm{Bu}(11) ; \mathrm{Cp}^{\prime}=\mathrm{Cp} *, \mathrm{R}=\mathrm{Me}(12),{ }^{t} \mathrm{Bu}\right.$ (13)] in the presence of $\mathrm{MAO}$ cocatalyst ${ }^{a}$

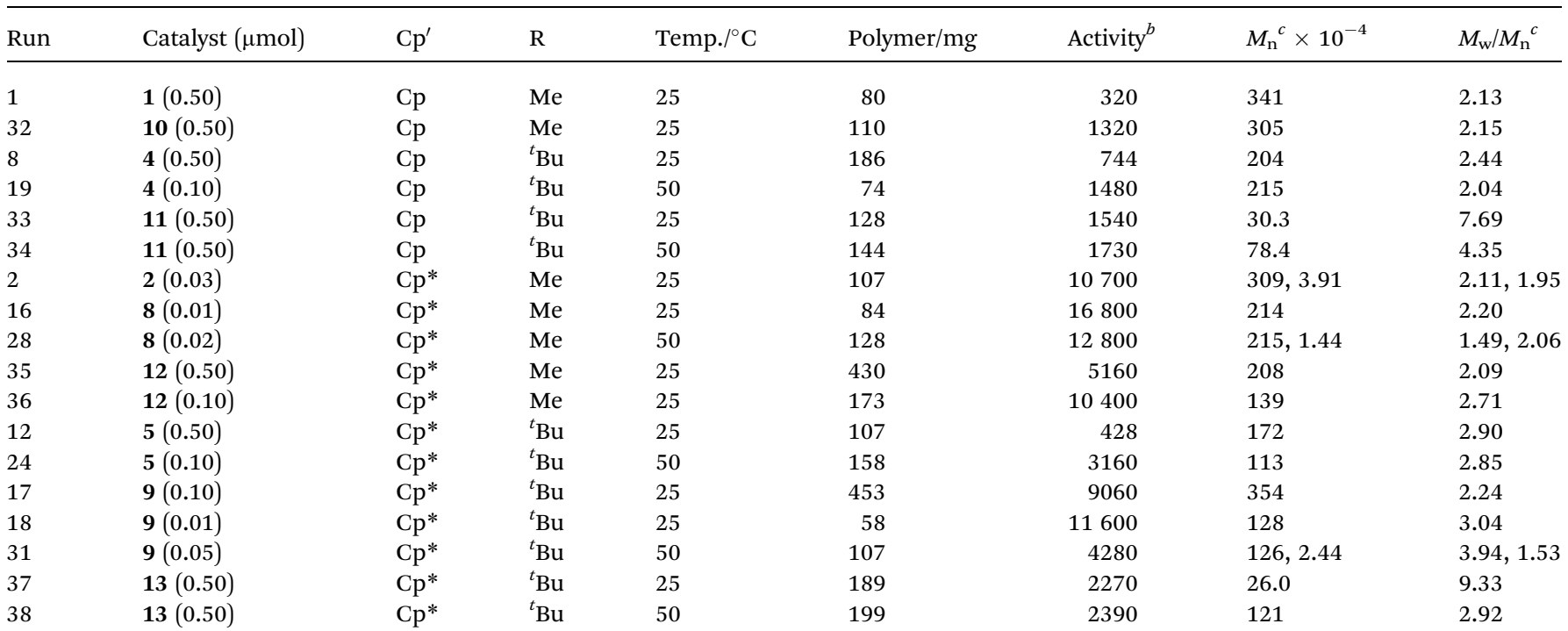

${ }^{a}$ Conditions: toluene total $30 \mathrm{~mL}$, d-MAO $3.0 \mathrm{mmol}$, ethylene $4 \mathrm{~atm}, 10 \mathrm{~min} .{ }^{b}$ Activity in $\mathrm{kg}$ PE per mol Ti per h. ${ }^{c}$ GPC data in $o$-dichlorobenzene $v s$. polystyrene standards.

Table 5 Ethylene polymerisation by $\left[\mathrm{Cp} * \mathrm{TiX}_{2}\left\{\left(\mathrm{O}-2,4-{ }^{t} \mathrm{Bu}_{2} \mathrm{C}_{6} \mathrm{H}_{2}\right)-6-\mathrm{CH}_{2}\right\}\right]_{3} \mathrm{~N}[\mathrm{X}=\mathrm{Cl}(5), \mathrm{Me}(9)]$, [Cp*TiMe $\left.\left\{\left(\mathrm{O}-2,4-\mathrm{Me}_{2} \mathrm{C}_{6} \mathrm{H}_{2}\right)-6-\mathrm{CH}_{2}\right\}\right]_{3} \mathrm{~N}(8)$, $\mathrm{Cp}^{*} \mathrm{TiCl}_{2}\left(2-\mathrm{R}-4,6-\mathrm{Me}_{2} \mathrm{C}_{6} \mathrm{H}_{2}\right)\left[\mathrm{R}=\mathrm{Me}(12),{ }^{t} \mathrm{Bu}(13)\right]$ in the presence of $\mathrm{Al}^{i} \mathrm{Bu}_{3} /\left[\mathrm{Ph}_{3} \mathrm{C}\right]\left[\mathrm{B}\left(\mathrm{C}_{6} \mathrm{~F}_{5}\right)_{4}\right]$ cocatalysts ${ }^{a}$

\begin{tabular}{|c|c|c|c|c|c|c|c|}
\hline Run & Catalyst $(\mu \mathrm{mol})$ & $\mathrm{Al} / \mathrm{Ti}^{b}$ & Temp. $/{ }^{\circ} \mathrm{C}$ & Polymer/mg & Activity $^{c}$ & $M_{\mathrm{n}}^{d} \times 10^{-4}$ & $M_{\mathrm{w}} / M_{\mathrm{n}}{ }^{d}$ \\
\hline 39 & $5(0.02)$ & 700 & 25 & 71 & 7100 & 71.6 & 3.37 \\
\hline 40 & $8(0.02)$ & 100 & 25 & Trace & & & \\
\hline 42 & $8(0.01)$ & 500 & 25 & 84 & 16800 & 88.1 & 3.79 \\
\hline 43 & $8(0.01)$ & 700 & 25 & 138 & 27600 & 115 & 3.15 \\
\hline 44 & $8(0.01)$ & 900 & 25 & 36 & 7200 & 70.8 & 3.33 \\
\hline 47 & $9(0.02)$ & 700 & 25 & 20 & 2000 & 78.5 & 4.21 \\
\hline 48 & $12(0.03)$ & 700 & 25 & 109 & 21800 & 63.7 & 4.17 \\
\hline 49 & $13(0.06)$ & 700 & 25 & 85 & 8500 & 54.9 & 2.82 \\
\hline
\end{tabular}

${ }^{a}$ Conditions: toluene total $30 \mathrm{~mL}, \mathrm{Al}^{\mathrm{i}} \mathrm{Bu}_{3},\left[\mathrm{Ph}_{3} \mathrm{C}\right]\left[\mathrm{B}\left(\mathrm{C}_{6} \mathrm{~F}_{5}\right)_{4}\right] \mathrm{B} / \mathrm{Ti}=1.5$ (molar ratio), 4 atm, $10 \mathrm{~min} .{ }^{b}$ Molar ratio. ${ }^{c}$ Activity in kg $\mathrm{PE}$ per mol Ti per h.

${ }^{d}$ GPC data in $o$-dichlorobenzene $v s$. polystyrene standards.

37, 38). ${ }^{18}$ Moreover, the activities by the dimethyl analogue, $\left[\mathrm{Cp} * \mathrm{TiMe}_{2}\left\{\left(\mathrm{O}-2,4-{ }^{t} \mathrm{Bu}_{2} \mathrm{C}_{6} \mathrm{H}_{2}\right)-6-\mathrm{CH}_{2}\right\}\right]_{3} \mathrm{~N}$ (9) were higher than those by 13 (runs 17, 31 vs. runs 37,38 ) conducted under the same conditions. Therefore, we believe that these would be unique characteristics observed by placement of three titanium complexes in tris(phenoxy)amine ligand.

It was revealed that the activities in the ethylene polymerisation by $\left[\mathrm{Cp}^{*} \mathrm{TiX}_{2}\left\{\left(\mathrm{O}-2,4-\mathrm{R}_{2} \mathrm{C}_{6} \mathrm{H}_{2}\right)-6-\mathrm{CH}_{2}\right\}\right]_{3} \mathrm{~N}\left[\mathrm{R}={ }^{t} \mathrm{Bu}, \mathrm{X}=\mathrm{Cl}(5) ; \mathrm{R}\right.$ $=\mathrm{Me}, \mathrm{X}=\mathrm{Me}(\mathbf{8})$, Table 5] in the presence of $\mathrm{Al}^{\mathrm{i}} \mathrm{Bu}_{3}-\left[\mathrm{Ph}_{3} \mathrm{C}\right]$ $\left[\mathrm{B}\left(\mathrm{C}_{6} \mathrm{~F}_{5}\right)_{4}\right]$ cocatalysts were higher than those in the presence of MAO under the optimized conditions (run 39 vs. run 12; run 43 vs. run 16$).{ }^{18}$ Similar trends were observed in the mononuclear analogues (12 and 13), whereas the activity by 9 in the presence of $\mathrm{Al}^{\mathrm{i}} \mathrm{Bu}_{3}-\left[\mathrm{Ph}_{3} \mathrm{C}\right]\left[\mathrm{B}\left(\mathrm{C}_{6} \mathrm{~F}_{5}\right)_{4}\right]$ cocatalysts was lower than that in the presence of MAO (run 47 vs. run 17). The trinuclear complex (8) exhibited the highest catalytic activities affording ultrahigh molecular weight polymer with uniform molecular weight distribution (27 $600 \mathrm{~kg}$ PE per mol Ti per h, run 43, $M_{\mathrm{n}}=1.15 \times$ $\left.10^{6}, M_{\mathrm{w}} / M_{\mathrm{n}}=3.15\right)$. The $M_{\mathrm{n}}$ values in addition to the activity by 8 was affected by the $\mathrm{Al} / \mathrm{Ti}$ molar ratios (runs 40-44), and the polymerisations at $0{ }^{\circ} \mathrm{C}$ also afforded polymers with uniform molecular weight distributions without significant changes in the $M_{\mathrm{n}}$ values (runs 45,46 ). These might suggest that the major chain transfer would not be the chain transfer to $\mathrm{Al}$ in this catalysis.

\section{Concluding remarks}

A series of trinuclear half-titanocenes, $\left[\mathrm{Cp}^{\prime} \mathrm{TiCl}_{2}\left\{\left(\mathrm{O}-2,4-\mathrm{R}_{2} \mathrm{C}_{6} \mathrm{H}_{2}\right)-\right.\right.$ 6- $\left.\left.\mathrm{CH}_{2}\right\}\right]_{3} \mathrm{~N}\left[\mathrm{R}=\mathrm{Me}, \mathrm{Cp}^{\prime}=\mathrm{Cp}(\mathbf{1}) ; \mathrm{R}={ }^{t} \mathrm{Bu}, \mathrm{Cp}^{\prime}=\mathrm{Cp}\right.$ (4), $\mathrm{Cp}^{*}(5)$, 
$\left.{ }^{t} \mathrm{BuC}_{5} \mathrm{H}_{4}(6), 1,2,4-\mathrm{Me}_{3} \mathrm{C}_{5} \mathrm{H}_{2}(7)\right]$ and $\left[\mathrm{Cp} * \mathrm{TiMe}_{2}\left\{\left(\mathrm{O}-2,4-\mathrm{R}_{2} \mathrm{C}_{6} \mathrm{H}_{2}\right)-\right.\right.$ 6- $\left.\left.\mathrm{CH}_{2}\right\}\right]_{3} \mathrm{~N}\left[\mathrm{R}=\mathrm{Me}(8),{ }^{t} \mathrm{Bu}(9)\right]$, and the bimetallic complexes, $\left[\mathrm{Cp}^{\prime} \mathrm{TiCl}_{2}\left\{\left(\mathrm{O}-2,4-\mathrm{Me}_{2} \mathrm{C}_{6} \mathrm{H}_{2}\right)-6-\mathrm{CH}_{2}\right\}\right]\left[\mathrm{Cp}^{\prime} \operatorname{TiCl}\left\{\left(\mathrm{O}-2,4-\mathrm{Me}_{2} \mathrm{C}_{6} \mathrm{H}_{2}\right)-6-\right.\right.$ $\left.\left.\mathrm{CH}_{2}\right\}_{2}\right] \mathrm{N}\left[\mathrm{Cp}^{\prime}=\mathrm{Cp} *(2), 1,2,4-\mathrm{Me}_{3} \mathrm{C}_{5} \mathrm{H}_{2}(3)\right]$, have been prepared and identified. Structures of 1-5, 7 and 9 were determined by $\mathrm{X}$ ray crystallography, and all complexes fold distorted tetrahedral geometries around titanium and $\mathrm{Ti}-\mathrm{O}-\mathrm{C}$ (phenyl) bond angles were affected by ligand substituents (on cyclopentadienyl, phenyl and halogen or methyl). It was revealed that these complexes (2-9) are stable in solution $\left(25-80{ }^{\circ} \mathrm{C}\right)$ except the $\mathrm{Cp}$ analogue, $\left[\mathrm{CpTiCl}_{2}\left\{\left(\mathrm{O}-2,4-\mathrm{Me}_{2} \mathrm{C}_{6} \mathrm{H}_{2}\right)-6-\mathrm{CH}_{2}\right\}\right]_{3} \mathrm{~N}$ (1), that was unstable in solution and present as a mixture of the trinuclear complex (1), (proposed) binuclear analogue and $\mathrm{CpTiCl}_{3}$ and titanatrane, $\mathrm{CpTiCl}\left[\left(\mathrm{O}-2,4-\mathrm{Me}_{2} \mathrm{C}_{6} \mathrm{H}_{2}\right)-6-\mathrm{CH}_{2}\right]_{3} \mathrm{~N}$; an equilibrium between 1 and the binuclear species (and $\mathrm{CpTiCl}_{3}$ ) was observed depending upon temperature and concentration.

These complexes (2-9) exhibited from moderate to high catalytic activities for ethylene polymerisation in the presence of MAO cocatalyst, affording ultrahigh molecular weight polymers with uniform molecular weight distributions in most cases, especially in both the $\mathrm{Cp}$ and the $\mathrm{Cp}^{*}$ analogues; different polymerisation behaviours compared to the related mononuclear analogues observed. In particular, the $\mathrm{Cp}^{*}$ trinuclear analogue, $\left[\mathrm{Cp}^{*} \mathrm{TiMe}_{2}\left\{\left(\mathrm{O}-2,4-\mathrm{Me}_{2} \mathrm{C}_{6} \mathrm{H}_{2}\right)-6-\mathrm{CH}_{2}\right\}\right]_{3} \mathrm{~N}$ (8) showed higher catalytic activities than the related mononuclear analogue, $\mathrm{Cp}^{*} \mathrm{TiCl}_{2}\left(\mathrm{O}-2-\mathrm{R}-4,6-\mathrm{Me}_{2} \mathrm{C}_{6} \mathrm{H}_{2}\right)\left[\mathrm{R}=\mathrm{Me}(12),{ }^{t} \mathrm{Bu}(13)\right]$ conducted under the same conditions. The activities in the presence of $\mathrm{Al}^{\mathrm{i}} \mathrm{Bu}_{3}-\left[\mathrm{Ph}_{3} \mathrm{C}\right]\left[\mathrm{B}\left(\mathrm{C}_{6} \mathrm{~F}_{5}\right)_{4}\right]$ cocatalysts were higher than those in the presence of MAO in most cases, although the $M_{\mathrm{n}}$ values in the resultant polymers decreased compared to those in the presence of MAO cocatalyst with rather broad molecular weight distributions. We thus believe that information observed here should be promising as an effect of integration of the catalytically active species, and would introduce a new possibility for design of efficient catalysts for olefin polymerisation.

\section{Experimental section}

\section{General procedures}

All experiments were carried out under a nitrogen atmosphere in a Vacuum Atmospheres drybox unless otherwise specified. All chemicals used were of reagent grade and were purified by the standard purification procedures. Anhydrous grades of toluene, $n$-hexane, and dichloromethane (Kanto Kagaku Co. Ltd) was transferred into a bottle containing molecular sieves (mixture of $3 \mathrm{~A}$ and $4 \mathrm{~A} 1 / 16$, and $13 \mathrm{X}$ ) in the drybox, and was used without further purification. Ethylene for polymerisation was of polymerisation grade (purity $>99.9 \%$; Sumitomo Seika Co., Ltd.) and was used as received. $\mathrm{Cp} * \mathrm{TiCl}_{2}\left(\mathrm{O}-2-\mathrm{R}-4,6-\mathrm{Me}_{2} \mathrm{C}_{6} \mathrm{H}_{2}\right)[\mathrm{R}=\mathrm{Me}$ (12), $\left.{ }^{t} \mathrm{Bu}(13)\right]$ were prepared according to the reported procedure. ${ }^{14 b, c}$ Toluene and $\mathrm{AlMe}_{3}$ in the commercially available methylaluminoxane [TMAO, 9.5 wt\% (Al) toluene solution, Tosoh Finechem Co.] were removed under reduced pressure (at ca. $50{ }^{\circ} \mathrm{C}$ for removing toluene, $\mathrm{AlMe}_{3}$, and then heated at $>100{ }^{\circ} \mathrm{C}$ for $1 \mathrm{~h}$ for completion) in the drybox to give white solids. ${ }^{14 c}$
Elemental analyses were performed by using EAI CE-440 CHN/O/S Elemental Analyzer (Exeter Analytical, Inc.). All ${ }^{1} \mathrm{H}$ and ${ }^{13} \mathrm{C}$ NMR spectra were recorded on a Bruker AV500 spectrometer $\left(500.13 \mathrm{MHz}\right.$ for ${ }^{1} \mathrm{H}, 125.77 \mathrm{MHz}$ for $\left.{ }^{13} \mathrm{C}\right)$. All spectra were obtained in the solvent indicated at $25^{\circ} \mathrm{C}$ unless otherwise noted. Chemical shifts are given in $\mathrm{ppm}$ and are referenced to $\mathrm{SiMe}_{4}\left(\delta 0.00 \mathrm{ppm},{ }^{1} \mathrm{H},{ }^{13} \mathrm{C}\right)$. Coupling constants are given in $\mathrm{Hz}$. Molecular weights and molecular weight distributions for the resultant polymers were measured by gel permeation chromatography (Tosoh HLC-8121GPC/HT) using a RI-8022 detector (for high temperature; Tosoh Co.) with a polystyrene gel column (TSK gel GMHHR-H HT $\times 2,30 \mathrm{~cm} \times 7.8 \mathrm{~mm}$ i.d.), ranging from $<10^{2}$ to $<2.8 \times 10^{8} \mathrm{MW}$ at $140{ }^{\circ} \mathrm{C}$ using $o$-dichlorobenzene containing $0.05 \mathrm{w} / \mathrm{v} \%$ 2,6-di-tert-butyl-p-cresol as the solvent. The molecular weight was calculated by a standard procedure based on the calibration with standard polystyrene samples.

Synthesis of $\left[\mathrm{CpTiCl}_{2}\left\{\left(\mathrm{O}-2,4-\mathrm{Me}_{2} \mathrm{C}_{6} \mathrm{H}_{2}\right)-6-\mathrm{CH}_{2}\right\}\right]_{3} \mathrm{~N}$ (1). Into diethyl ether $\left(\mathrm{Et}_{2} \mathrm{O}\right)$ solution $(20 \mathrm{~mL})$ containing $\mathrm{CpTiCl}_{3}$ $(264 \mathrm{mg}, 1.20 \mathrm{mmol})$ was added $\mathrm{Et}_{2} \mathrm{O}$ solution $(10 \mathrm{~mL})$ containing [(LiO-2,4- $\left.\left.\mathrm{Me}_{2} \mathrm{C}_{6} \mathrm{H}_{2}\right)-6-\mathrm{CH}_{2}\right]_{3} \mathrm{~N}(175 \mathrm{mg}, 0.40 \mathrm{mmol})$, prepared by treating $\left[\left(\mathrm{HO}-2,4-\mathrm{Me}_{2} \mathrm{C}_{6} \mathrm{H}_{2}\right)-6-\mathrm{CH}_{2}\right]_{3} \mathrm{~N}$ with $n$-BuLi (equimolar to $\mathrm{OH}$ ) in $n$-hexane at $-30{ }^{\circ} \mathrm{C}$ and obtained as white precipitates, slowly at $-30{ }^{\circ} \mathrm{C}$. The stirred reaction mixture was then warmed slowly to room temperature, and the mixture was then stirred overnight $(16 \mathrm{~h})$. The solution was passed through a Celite pad, and the filter cake was washed with $\mathrm{Et}_{2} \mathrm{O}$. The combined filtrate and the wash were placed in a rotary evaporator to remove the volatiles. The resultant solid was dissolved in a minimum amount of $\mathrm{CH}_{2} \mathrm{Cl}_{2}$, and was then layered with $n$ hexane. The chilled solution placed in the freezer $\left(-30^{\circ} \mathrm{C}\right)$ afforded orange microcrystals $(310 \mathrm{mg})$. Yield: $80 \% .{ }^{1} \mathrm{H}$ NMR $\left(500 \mathrm{MHz}\right.$, toluene- $\left.d_{8},-60{ }^{\circ} \mathrm{C}\right): \delta 7.73(\mathrm{~s}, 3 \mathrm{H}), 6.57(\mathrm{~s}, 3 \mathrm{H}), 6.07$ (s, 15H), 4.12 (bs, 6H), $2.40(\mathrm{~s}, 9 \mathrm{H}), 2.21(\mathrm{~s}, 9 \mathrm{H})$. Anal. calcd $\mathrm{C}_{42} \mathrm{H}_{45} \mathrm{Cl}_{6} \mathrm{O}_{3} \mathrm{NTi}_{3}$ (968.1): C, 52.11; H, 4.69; N, 1.45; found: C, 52.13; H, 4.97; N, 1.40 .

Synthesis of $\left[\mathrm{Cp}^{*} \mathrm{TiCl}_{2}\left\{\left(\mathrm{O}-2,4-\mathrm{Me}_{2} \mathrm{C}_{6} \mathrm{H}_{2}\right)-6-\mathrm{CH}_{2}\right\}\right][\mathrm{Cp} * \mathrm{TiCl}\{(\mathrm{O}-$ 2,4- $\mathbf{M e}_{2} \mathbf{C}_{6} \mathbf{H}_{2}$ )-6- $\left.\left.\mathbf{C H}_{2}\right\}_{2}\right] \mathbf{N}$ (2). The synthetic procedure for $\mathbf{2}$ was similar to that for $\mathbf{1}$, except that $\mathrm{Cp}^{*} \mathrm{TiCl}_{3}(234 \mathrm{mg}, 0.80 \mathrm{mmol})$ in place of $\mathrm{CpTiCl}_{3}(1.20 \mathrm{mmol})$ was used. The resultant solid after removal of $\mathrm{Et}_{2} \mathrm{O}$ (and volatile) was dissolved in a minimum amount of $\mathrm{CH}_{2} \mathrm{Cl}_{2}$, and was then layered with $n$-hexane. The chilled solution placed in the freezer $\left(-30{ }^{\circ} \mathrm{C}\right)$ afforded red microcrystals $\left(123 \mathrm{mg}\right.$ ). Yield: $35 \%$ (based on ligand). ${ }^{1} \mathrm{H}$ NMR $\left(500 \mathrm{MHz}, \mathrm{CDCl}_{3}\right) \delta 6.63(\mathrm{~s}, 2 \mathrm{H}), 6.60(\mathrm{~s}, 2 \mathrm{H}), 6.50(\mathrm{~s}, 1 \mathrm{H}), 6.24(\mathrm{~s}$, $1 \mathrm{H}), 3.98(\mathrm{~d}, J=12.3 \mathrm{~Hz}, 2 \mathrm{H}), 3.47(\mathrm{~s}, 2 \mathrm{H}), 3.34(\mathrm{~d}, J=12.3 \mathrm{~Hz}$, $2 \mathrm{H}), 2.23(\mathrm{~s}, 6 \mathrm{H}), 2.18(\mathrm{~s}, 15 \mathrm{H}), 2.14(\mathrm{~s}, 15 \mathrm{H}), 2.12(\mathrm{~s}, 6 \mathrm{H}), 2.00(\mathrm{~s}$, 3H), $1.96(\mathrm{~s}, 3 \mathrm{H}) .{ }^{13} \mathrm{C}$ NMR $\left(126 \mathrm{MHz}, \mathrm{CDCl}_{3}\right) \delta$ 161.7, 158.7, 132.6, 131.8, 131.1, 130.2, 129.6, 129.4, 128.6, 128.2, 127.9, $127.5,126.9,61.6,51.2,20.8,20.6,17.0,16.9,12.9,12.4$. Anal. calcd $\mathrm{C}_{47} \mathrm{H}_{60} \mathrm{Cl}_{3} \mathrm{O}_{3} \mathrm{NTi}_{2}$ (889.1): C, 63.49; $\mathrm{H}, 6.80 ; \mathrm{N}, 1.58$; found: $\mathrm{C}, 63.74 ; \mathrm{H}, 6.82 ; \mathrm{N}, 1.47$.

Synthesis of $\left[\left(1,2,4-\mathrm{Me}_{3} \mathrm{C}_{5} \mathrm{H}_{2}\right) \mathrm{TiCl}_{2}\left\{\left(\mathrm{O}-2,4-\mathrm{Me}_{2} \mathrm{C}_{6} \mathrm{H}_{2}\right)-6-\mathrm{CH}_{2}\right\}\right]$ $\left[\left(\mathbf{1}, \mathbf{2}, \mathbf{4}-\mathrm{Me}_{3} \mathrm{C}_{5} \mathbf{H}_{2}\right) \operatorname{TiCl}\left\{\left(\mathbf{O}-\mathbf{2}, \mathbf{4}-\mathrm{Me}_{2} \mathrm{C}_{6} \mathbf{H}_{2}\right)-\mathbf{6}-\mathrm{CH}_{2}\right\}_{2}\right] \mathbf{N} \quad$ (3). The synthetic procedure for $\mathbf{3}$ was similar to that for $\mathbf{1}$, except that $\left(1,2,4-\mathrm{Me}_{3} \mathrm{C}_{5} \mathrm{H}_{2}\right) \mathrm{TiCl}_{3}(209 \mathrm{mg}, 0.80 \mathrm{mmol})$ in place of $\mathrm{CpTiCl}_{3}$ $(1.20 \mathrm{mmol})$ was used. The resultant solid after removal of $\mathrm{Et}_{2} \mathrm{O}$ (and volatile) was dissolved in a minimum amount of $\mathrm{CH}_{2} \mathrm{Cl}_{2}$, 
and was then layered with $n$-hexane. The chilled solution placed in the freezer $\left(-30{ }^{\circ} \mathrm{C}\right)$ afforded orange-red microcrystals (160 mg). Yield: 48\% (based on ligand). ${ }^{1} \mathrm{H}$ NMR $(500 \mathrm{MHz}$, $\left.\mathrm{CDCl}_{3}\right) \delta 6.73(\mathrm{~s}, 1 \mathrm{H}), 6.68(\mathrm{~s}, 2 \mathrm{H}), 6.65(\mathrm{~s}, 2 \mathrm{H}), 6.40(\mathrm{~s}, 1 \mathrm{H}), 6.15$ $(\mathrm{s}, 2 \mathrm{H}), 6.10(\mathrm{~s}, 2 \mathrm{H}), 4.05(\mathrm{~d}, J=12.9 \mathrm{~Hz}, 2 \mathrm{H}), 3.57(\mathrm{~s}, 2 \mathrm{H}), 3.42$ (d, $J=12.9 \mathrm{~Hz}, 2 \mathrm{H}), 2.23(\mathrm{~s}, 6 \mathrm{H}), 2.18(\mathrm{~s}, 6 \mathrm{H}), 2.17(\mathrm{~s}, 12 \mathrm{H}), 2.15$ (s, 3H), $2.12(\mathrm{~s}, 3 \mathrm{H}), 2.09$ (s, 3H), 2.03 (s, 3H). ${ }^{13} \mathrm{C}$ NMR (126 $\left.\mathrm{MHz}, \mathrm{CDCl}_{3}\right) \delta 161.9,161.3,134.5,134.4,132.9,131.1,130.3$, 130.2 , 129.8, 129.4, 129.2, 128.4, 128.2, 127.4, 126.5, 121.3, 118.5, 60.6, 51.3, 20.9, 20.7, 17.0, 16.8, 16.2, 15.0, 14.6, 13.7. Anal. calcd $\mathrm{C}_{47} \mathrm{H}_{60} \mathrm{Cl}_{3} \mathrm{O}_{3} \mathrm{NTi}_{2}$ (889.1): C, 62.00; H, 6.29; N, 1.68; found: C, 62.18; H, 6.40; N, 1.59 .

Synthesis of $\left[\mathrm{CpTiCl}_{2}\left\{\left(\mathrm{O}-2,4-{ }^{t}{ }^{\mathrm{Bu}_{2}} \mathrm{C}_{6} \mathrm{H}_{2}\right)-6-\mathrm{CH}_{2}\right\}\right]_{3} \mathbf{N}$ (4). The synthetic procedure for 4 was similar to that for $\mathbf{1}$, except that (LiO-2,4- $\left.{ }^{t} \mathrm{Bu}_{2} \mathrm{C}_{6} \mathrm{H}_{2}-6-\mathrm{CH}_{2}\right)_{3} \mathrm{~N}(276 \mathrm{mg}, 0.40 \mathrm{mmol})$ was used in place of (LiO-2,4- $\left.\mathrm{Me}_{2} \mathrm{C}_{6} \mathrm{H}_{2}-6-\mathrm{CH}_{2}\right)_{3} \mathrm{~N}$. The resultant solid after removal of $\mathrm{Et}_{2} \mathrm{O}$ (and volatile) was dissolved in a minimum amount of $\mathrm{CH}_{2} \mathrm{Cl}_{2}$, and was then layered with $n$-hexane. The chilled solution placed in the freezer $\left(-30{ }^{\circ} \mathrm{C}\right)$ afforded red microcrystals (353 mg). Yield: $72 \% .{ }^{1} \mathrm{H}$ NMR (500 $\mathrm{MHz}, \mathrm{CDCl}_{3}$ ) $\delta 7.70(\mathrm{~s}, 3 \mathrm{H}), 7.20(\mathrm{~s}, 3 \mathrm{H}), 6.67(\mathrm{~s}, 15 \mathrm{H}), 3.95(\mathrm{~s}, 6 \mathrm{H}), 1.38(\mathrm{~s}$, 27H), 1.21 (s, 27H). $\left.{ }^{13} \mathrm{C} \mathrm{NMR} \mathrm{(126} \mathrm{MHz,} \mathrm{CDCl}_{3}\right) \delta$ 165.1, 146.6, 137.7, 130.9, 123.0, 122.1, 121.4, 55.1, 35.4, 34.8, 31.5, 30.6. Anal. calcd $\mathrm{C}_{60} \mathrm{H}_{81} \mathrm{Cl}_{6} \mathrm{O}_{3} \mathrm{NTi}_{3}$ (1220.6): C, 59.04; H, 6.69; N, 1.15; found: C, 58.74; H, 6.90; N, 1.00 .

Synthesis of $\left[\mathrm{Cp}^{*} \mathrm{TiCl}_{2}\left\{\left(\mathbf{O}-2,4-{ }^{t} \mathrm{Bu}_{2} \mathrm{C}_{6} \mathbf{H}_{2}\right)-6-\mathrm{CH}_{2}\right\}\right]_{3} \mathbf{N}$ (5). The synthetic procedure for $\mathbf{5}$ was similar to that for $\mathbf{4}$, except that $\mathrm{Cp}^{*} \mathrm{TiCl}_{3}$ (348 mg, $1.20 \mathrm{mmol}$ ) was used in place of $\mathrm{CpTiCl}_{3}$. The resultant solid after removal of $\mathrm{Et}_{2} \mathrm{O}$ (and volatile) was dissolved in a minimum amount of $\mathrm{CH}_{2} \mathrm{Cl}_{2}$, and was then layered with $n$ hexane. The chilled solution placed in the freezer $\left(-30{ }^{\circ} \mathrm{C}\right)$ afforded red microcrystals (356 mg). Yield: $62 \%$. ${ }^{1} \mathrm{H}$ NMR $\left(500 \mathrm{MHz}, \mathrm{CDCl}_{3}\right) \delta 8.09(\mathrm{~s}, 3 \mathrm{H}), 7.21(\mathrm{~s}, 3 \mathrm{H}), 4.11(\mathrm{~d}, J=16.8 \mathrm{~Hz}$, $3 \mathrm{H}), 3.79(\mathrm{~d}, J=16.8 \mathrm{~Hz}, 3 \mathrm{H}), 1.98(\mathrm{~s}, 45 \mathrm{H}), 1.36(\mathrm{~s}, 27 \mathrm{H}), 1.26$ (s, 27H). ${ }^{13} \mathrm{C}$ NMR $\left(126 \mathrm{MHz}, \mathrm{CDCl}_{3}\right) \delta 160.5,145.2,138.8$, 133.27, 132.1, 121.7, 121.6, 52.7, 35.2, 34.8, 31.7, 30.7, 13.3. Anal. calcd $\mathrm{C}_{75} \mathrm{H}_{111} \mathrm{Cl}_{6} \mathrm{O}_{3} \mathrm{NTi}_{3}$ (1431): C, 62.95; H, 7.81; N, 0.98; found: C, 62.86; H, 7.91; N, 0.97.

Synthesis of $\left[\left({ }^{t} \mathrm{BuC}_{5} \mathrm{H}_{4}\right) \mathrm{TiCl}_{2}\left\{\left(\mathrm{O}-2,4{ }^{-}{ }^{t} \mathrm{Bu}_{2} \mathrm{C}_{6} \mathrm{H}_{2}\right)-6-\mathrm{CH}_{2}\right\}\right]_{3} \mathrm{~N}(6)$. The synthetic procedure for $\mathbf{6}$ was similar to that for $\mathbf{4}$, except that $\left({ }^{t} \mathrm{BuC}_{5} \mathrm{H}_{4}\right) \mathrm{TiCl}_{3}(331 \mathrm{mg}, 1.20 \mathrm{mmol})$ was used in place of $\mathrm{CpTiCl}_{3}$. The resultant solid after removal of $\mathrm{Et}_{2} \mathrm{O}$ (and volatile) was dissolved in a minimum amount of $\mathrm{CH}_{2} \mathrm{Cl}_{2}$, and was then layered with $n$-hexane. The chilled solution placed in the freezer $\left(-30{ }^{\circ} \mathrm{C}\right)$ afforded red microcrystals $(324 \mathrm{mg})$. Yield: $56.2 \% .{ }^{1} \mathrm{H}$ NMR (500 MHz, $\left.\mathrm{CDCl}_{3}\right) \delta 7.65(\mathrm{~d}, J=2.1 \mathrm{~Hz}, 3 \mathrm{H}), 7.19(\mathrm{~d}, J=$ $2.3 \mathrm{~Hz}, 3 \mathrm{H}), 6.81(\mathrm{t}, J=2.7 \mathrm{~Hz}, 6 \mathrm{H}), 6.11(\mathrm{t}, J=2.7 \mathrm{~Hz}, 6 \mathrm{H}), 4.01$ $(\mathrm{s}, 6 \mathrm{H}), 1.43(\mathrm{~s}, 27 \mathrm{H}), 1.38(\mathrm{~s}, 27 \mathrm{H}), 1.17(\mathrm{~s}, 27 \mathrm{H}) .{ }^{13} \mathrm{C}$ NMR $\left(126 \mathrm{MHz}, \mathrm{CDCl}_{3}\right) \delta 165.2,151.8,146.3,137.5,130.8,123.0$, 122.0, 120.1, 119.6, 55.5, 35.4, 34.8, 34.1, 31.5, 30.9, 30.7. Anal. calcd for $\mathrm{C}_{72} \mathrm{H}_{105} \mathrm{Cl}_{6} \mathrm{O}_{3} \mathrm{NTi}_{3}$ (1388.9): C, 62.54; H, 7.82; N, 0.99; found: C, 62.58; H, 7.63; N, 0.90.

Synthesis of $\left[\left(1,2,4-\mathrm{Me}_{3} \mathrm{C}_{5} \mathrm{H}_{2}\right) \mathrm{TiCl}_{2}\left\{\left(\mathrm{O}-2,4-{ }^{t} \mathrm{Bu}_{2} \mathrm{C}_{6} \mathrm{H}_{2}\right)-6\right.\right.$ $\left.\left.\mathbf{C H}_{2}\right\}\right]_{3} \mathbf{N}$ (7). The synthetic procedure for 7 was similar to that for 4, except that $\left(1,2,4-\mathrm{Me}_{3} \mathrm{C}_{5} \mathrm{H}_{2}\right) \mathrm{TiCl}_{3}(314 \mathrm{mg}, 1.20 \mathrm{mmol})$ was used in place of $\mathrm{CpTiCl}_{3}$. The resultant solid after removal of $\mathrm{Et}_{2} \mathrm{O}$ (and volatile) was dissolved in a minimum amount of
$\mathrm{CH}_{2} \mathrm{Cl}_{2}$, and was then layered with $n$-hexane. The chilled solution placed in the freezer $\left(-30{ }^{\circ} \mathrm{C}\right)$ afforded red microcrystals (324 mg). Yield: 60\%. ${ }^{1} \mathrm{H}$ NMR (500 $\left.\mathrm{MHz}, \mathrm{CDCl}_{3}\right) \delta 7.97(\mathrm{~d}, J=$ $2.1 \mathrm{~Hz}, 3 \mathrm{H}), 7.19$ (d, $J=2.2 \mathrm{~Hz}, 3 \mathrm{H}), 5.99(\mathrm{~s}, 6 \mathrm{H}), 4.03(\mathrm{~s}, 6 \mathrm{H})$, $2.16(\mathrm{~s}, 18 \mathrm{H}), 1.98(\mathrm{~s}, 9 \mathrm{H}), 1.36(\mathrm{~s}, 27 \mathrm{H}), 1.24(\mathrm{~s}, 27 \mathrm{H}) .{ }^{13} \mathrm{C} \mathrm{NMR}$ $\left(126 \mathrm{MHz}, \mathrm{CDCl}_{3}\right) \delta 161.1,145.7,138.4,135.0,134.0,131.7$, 123.0, 122.1, 121.8, 54.1, 35.3, 34.8, 31.6, 30.3, 15.6, 14.5. Anal. calcd for $\mathrm{C}_{69} \mathrm{H}_{99} \mathrm{Cl}_{6} \mathrm{O}_{3} \mathrm{NTi}_{3}$ (1346.9): C, 61.53; H, 7.41; N, 1.04; found: C, 61.66; $\mathrm{H}, 7.47$;, 0.97.

Synthesis of $\left[\mathrm{Cp}^{*} \mathrm{TiMe}_{2}\left\{\left(\mathrm{O}-2,4-\mathrm{Me}_{2} \mathrm{C}_{6} \mathrm{H}_{2}\right)-6-\mathrm{CH}_{2}\right\}\right]_{3} \mathbf{N}(8)$. Into a toluene solution $(18 \mathrm{~mL})$ containing $\mathrm{Cp}^{*} \mathrm{TiCl}_{3}(261 \mathrm{mg}$, $0.90 \mathrm{mmol})$ was added MeLi $\left(2.75 \mathrm{mmol}\right.$, in $2.5 \mathrm{~mL} \mathrm{Et}_{2} \mathrm{O}$ solution) slowly at $-30{ }^{\circ} \mathrm{C}$. The stirred reaction mixture was warmed slowly to room temperature, and the mixture covered by $\mathrm{Al}$ foil was then stirred for $3 \mathrm{~h}$. Into the solution, toluene solution $(6.0 \mathrm{~mL})$ containing $\left[\left(\mathrm{HO}-2,4-\mathrm{Me}_{2} \mathrm{C}_{6} \mathrm{H}_{2}\right)-6-\mathrm{CH}_{2}\right]_{3} \mathrm{~N}(126 \mathrm{mg}$, $0.30 \mathrm{mmol}$ ) was then added by several portions at $-30{ }^{\circ} \mathrm{C}$, and the reaction mixture was warmed slowly to room temperature, and was then stirred overnight. The solution was then placed in a rotary evaporator to remove the volatiles. The residues were dissolved in $n$-hexane, and the solution was passed through a Celite pad, and the filter cake was washed with $n$-hexane. The combined filtrate and the wash were placed in a rotary evaporator to remove the volatiles. The crude product was dissolved in a minimum amount of $n$-hexane. The chilled solution placed in the freezer $\left(-30{ }^{\circ} \mathrm{C}\right)$ afforded yellow microcrystals $(262 \mathrm{mg})$. Yield 83\%. ${ }^{1} \mathrm{H}$ NMR $\left(500 \mathrm{MHz}, \mathrm{CDCl}_{3}\right) \delta 7.44(\mathrm{~s}, 3 \mathrm{H}), 6.79(\mathrm{~s}, 3 \mathrm{H})$, $3.64(\mathrm{~s}, 6 \mathrm{H}), 2.26$ (s, 9H), 2.10 (s, 9H), 1.81 (s, 45H), $0.42(\mathrm{~s}, 18 \mathrm{H})$. ${ }^{13} \mathrm{C} \mathrm{NMR}\left(126 \mathrm{MHz}, \mathrm{CDCl}_{3}\right.$ ) $\delta 158.86$ (s), $129.66(\mathrm{~s}), 129.58(\mathrm{~s})$, 128.68 (s), 127.07 (s), 125.86 (s), 122.10 (s), 54.22 (s), 53.55 (s), $21.16(\mathrm{~s}), 17.14(\mathrm{~s}), 11.42$ (s). Anal. calcd $\mathrm{C}_{63} \mathrm{H}_{93} \mathrm{O}_{3} \mathrm{NTi}_{3}$ (1056.0): C, 71.65; H, 8.88; N, 1.33; found: C, 71.49; H, 9.18; N, 1.27.

Synthesis of $\left[\mathrm{Cp}^{*} \mathrm{TiMe}_{2}\left\{\left(\mathrm{O}-2,4-{ }^{t} \mathrm{Bu}_{2} \mathrm{C}_{6} \mathrm{H}_{2}\right)-6-\mathrm{CH}_{2}\right\}\right]_{3} \mathrm{~N}$ (9). Into an $\mathrm{Et}_{2} \mathrm{O}$ solution $(7.0 \mathrm{~mL})$ containing $\left[\mathrm{Cp}^{*} \mathrm{TiCl}_{2}\{(\mathrm{O}-\right.$ 2,4- ${ }^{t} \mathrm{Bu}_{2} \mathrm{C}_{6} \mathrm{H}_{2}$ )-6- $\left.\left.\mathrm{CH}_{2}\right\}\right]_{3} \mathrm{~N}(5)$ (71.6 mg, $0.05 \mathrm{mmol}$ ) was added $\mathrm{MeMgBr}\left(3 \mathrm{M}\right.$ in $\mathrm{Et}_{2} \mathrm{O}, 0.10 \mathrm{~mL}$ ) slowly at $-30{ }^{\circ} \mathrm{C}$. The stirred reaction mixture was warmed slowly to room temperature, and the mixture was then stirred for $3 \mathrm{~h}$. The solution was placed in a rotary evaporator to remove the $\mathrm{Et}_{2} \mathrm{O}$. The resultant solid was dissolved in toluene and passed through a Celite pad, and the filter cake was washed with toluene. The combined filtrate and the wash were placed in a rotary evaporator to remove the volatiles. The resultant solid was dissolved in a minimum amount of toluene, and was then layered with $n$-hexane. The chilled solution placed in the freezer $\left(-30^{\circ} \mathrm{C}\right)$ afforded orange microcrystals (50 mg). Yield: 76.5\%. ${ }^{1} \mathrm{H}$ NMR (500 $\mathrm{MHz}, \mathrm{CDCl}_{3}$ ) $\delta 7.98(\mathrm{~d}, J=2.1 \mathrm{~Hz}, 3 \mathrm{H}), 7.16(\mathrm{~d}, J=2.1 \mathrm{~Hz}, 3 \mathrm{H}), 3.39$ (d, $J=$ $3.5 \mathrm{~Hz}, 6 \mathrm{H}), 1.72(\mathrm{~s}, 45 \mathrm{H}), 1.41(\mathrm{~s}, 27 \mathrm{H}), 1.22(\mathrm{~s}, 27 \mathrm{H}), 0.47$ (s, 9H), 0.42 (s, 9H). ${ }^{13} \mathrm{C}$ NMR (126 MHz, $\left.\mathrm{CDCl}_{3}\right) \delta$ 159.52, 142.80, $137.06,130.98,122.87,121.84,121.29$, 77.41, 77.16, 76.91, $58.35,56.64,53.92,35.23,34.71,31.97,30.76,11.87$. Anal. calcd $\mathrm{C}_{81} \mathrm{H}_{129} \mathrm{O}_{3} \mathrm{NTi}_{3}$ (1308.5): C, 74.35; H, 9.94; N, 1.07; found: C, 74.19; H, 9.76; N, 1.00 .

Synthesis of $\mathrm{CpTiCl}_{2}\left(\mathbf{O}-2,4,6-\mathrm{Me}_{3} \mathrm{C}_{6} \mathrm{H}_{2}\right)$ (10). Complexes 10 was prepared according the analogous procedure for synthesis of the Cp-aryloxo analogues. ${ }^{\mathbf{1 0 i}, \mathbf{1 4 b}, \boldsymbol{c}}$ To an $\mathrm{Et}_{2} \mathrm{O}$ solution $(20 \mathrm{~mL})$ containing $\mathrm{CpTiCl}_{3}(219 \mathrm{mg}, 1.00 \mathrm{mmol}$ ) was added LiO-2,4,6- 
$\mathrm{Me}_{3} \mathrm{C}_{6} \mathrm{H}_{2}(142 \mathrm{mg}, 1.00 \mathrm{mmol})$ at $-30{ }^{\circ} \mathrm{C}$. The reaction mixture was warmed slowly to room temperature, and the mixture was then stirred overnight. The solution was passed through a Celite pad, and the filter cake was washed with $\mathrm{Et}_{2} \mathrm{O}$. The combined filtrate and the wash were placed in a rotary evaporator to remove the volatiles. The resultant solid was dissolved in a minimum amount of $\mathrm{Et}_{2} \mathrm{O}$, and was then layered with $n$ hexane. The chilled solution placed in the freezer $\left(-30{ }^{\circ} \mathrm{C}\right)$ afforded brown microcrystals. Yield: $180 \mathrm{mg}$ (56.4\%). ${ }^{1} \mathrm{H}$ NMR $\left(500 \mathrm{MHz}, \mathrm{CDCl}_{3}\right) \delta 6.80(\mathrm{~s}, 2 \mathrm{H}), 6.71(\mathrm{~s}, 5 \mathrm{H}), 2.26(\mathrm{~s}, 3 \mathrm{H}), 2.25(\mathrm{~s}$, $6 \mathrm{H}) .{ }^{13} \mathrm{C}$ NMR $\left(126 \mathrm{MHz}, \mathrm{CDCl}_{3}\right) \delta$ 165.4, 133.8, 129.0, 127.3, 120.8, 20.8, 17.2. Anal. calcd $\mathrm{C}_{14} \mathrm{H}_{16} \mathrm{Cl}_{2} \mathrm{OTi}$ : C, 52.70; H, 5.06; found: C, 52.89; H, 4.97.

Synthesis of $\mathrm{CpTiCl}_{2}\left(\mathrm{O}-2-{ }^{-}{ }^{\mathrm{Bu}}-4,6-\mathrm{Me}_{2} \mathrm{C}_{6} \mathrm{H}_{2}\right)$ (11). The synthetic procedure for $\mathbf{1 1}$ was similar to that for 10, except that LiO-2- ${ }^{t} \mathrm{Bu}-4,6-\mathrm{Me}_{2} \mathrm{C}_{6} \mathrm{H}_{2}(184 \mathrm{mg}, 1.0 \mathrm{mmol})$ was used in place of LiO-2,4,6- $\mathrm{Me}_{3} \mathrm{C}_{6} \mathrm{H}_{2}$. Yield: $250 \mathrm{mg}(69.2 \%) .{ }^{1} \mathrm{H}$ NMR $(500 \mathrm{MHz}$, $\left.\mathrm{CDCl}_{3}\right) \delta 6.94(\mathrm{~s}, 1 \mathrm{H}), 6.87(\mathrm{~s}, 1 \mathrm{H}), 6.76(\mathrm{~s}, 5 \mathrm{H}), 2.36(\mathrm{~s}, 3 \mathrm{H}), 2.29$ $(\mathrm{s}, 3 \mathrm{H}), 1.40(\mathrm{~s}, 9 \mathrm{H}) .{ }^{13} \mathrm{C} \mathrm{NMR}\left(126 \mathrm{MHz} \mathrm{CDCl}_{3}\right) \delta 165.8,138.2$, 133.4, 130.0, 129.4, 125.2, 121.1, 35.0, 30.4, 21.1, 18.9. Anal. calcd $\mathrm{C}_{17} \mathrm{H}_{22} \mathrm{Cl}_{2} \mathrm{OTi}$ : C, 56.54; H, 6.14; found: C, 56.60; H, 6.11.

\section{Polymerisation of ethylene}

Reactions with ethylene were conducted in a $100 \mathrm{~mL}$ scale stainless steel autoclave, and the typical reaction procedure is as follows. Toluene $(29.0 \mathrm{~mL})$ and prescribed amount of MAO were added into the autoclave in the drybox. The reaction apparatus was then filled with ethylene ( $1 \mathrm{~atm})$, and the prescribed amount of complex in toluene $(1.0 \mathrm{~mL})$ was added into the autoclave. The reaction apparatus was then immediately pressurized to $3 \mathrm{~atm}$ (total $4 \mathrm{~atm}$ ), and the mixture was magnetically stirred for 5 or $10 \mathrm{~min}$ (ethylene pressure was kept constant during the reaction). After the above procedure, the mixture in the autoclave was poured into $\mathrm{MeOH}$ containing $\mathrm{HCl}$, and the resultant polymer (white precipitate) was collected on a filter paper by filtration and was adequately washed with $\mathrm{MeOH}$. The resultant polymer was then dried in vacuo at $60{ }^{\circ} \mathrm{C}$ for $2 \mathrm{~h}$.

\section{Crystallographic analysis}

All measurements were made on a Rigaku XtaLAB P200 diffractometer using multi-layer mirror monochromated Mo-K $\alpha$ radiation. The crystal collection parameters are listed in Tables S5 and S6 (ESI $\dagger$ ). The data were collected and processed using CrystalClear (Rigaku) ${ }^{19}$ or CrysAlisPro (Rigaku Oxford Diffraction $),{ }^{20}$ and the structure was solved by direct methods ${ }^{21}$ and expanded using Fourier techniques. The non-hydrogen atoms were refined anisotropically. Hydrogen atoms were refined using the riding model. All calculations were performed using the Crystal Structure ${ }^{22}$ crystallographic software package except for refinement, which was performed using SHELXL Version 2014/7. ${ }^{23}$ Details are shown in the ESI. $\dagger^{17}$ CCDC numbers for complexes 1-5, 7 and 9 are CCDC 1549581-1549587, respectively.

\section{Conflicts of interest}

There are no conflicts to declare.

\section{Acknowledgements}

This project was partly supported by Grant-in-Aid for Scientific Research (B) from the Japan Society for the Promotion of Science (JSPS, No. 15H03812). The authors express their thanks to Profs. S. Komiya, A. Inagaki, and Dr S. Sueki (Tokyo Metropolitan Univ.) for discussions, and to Tosoh Finechem Co. for donating MAO.

\section{Notes and references}

1 Selected reviews, accounts in 1990's, see: (a) R. F. Jordan, Adv. Organomet. Chem., 1991, 32, 325; (b) H. H. Brintzinger, D. Fischer, R. Mülhaupt, B. Rieger and R. M. Waymouth, Angew. Chem., Int. Ed. Engl., 1995, 34, 1143; (c) W. Kaminsky and M. Arndt, Adv. Polym. Sci., 1997, 127, 144; (d) J. Suhm, J. Heinemann, C. Wörner, P. Müller, F. Stricker, J. Kressler, J. Okuda and R. Mülhaupt, Macromol. Symp., 1998, 129, 1; (e) A. L. McKnight and R. M. Waymouth, Chem. Rev., 1998, 98, 2587; (f) G. J. P. Britovsek, V. C. Gibson and D. F. Wass, Angew. Chem., Int. Ed., 1999, 38, 428; $(g)$ W. Kaminsky, J. Chem. Soc., Dalton Trans., 1998, 1413.

2 Selected special issues: (a) Frontiers in Metal-Catalyzed Polymerization (special issue), J. A. Gladysz, Chem. Rev., 2000, 100, 1167; (b) Metallocene complexes as catalysts for olefin polymerization, H. G. Alt, Coord. Chem. Rev., 2006, 250, 1; (c) Metal-catalysed Polymerisation, B. Milani and C. Claver, Dalton Trans., 2009, 8769; (d) Advances in MetalCatalysed Polymerisation and Related Transformations, P. Mountford, Dalton Trans., 2013, 42, 8977.

3 Selected recent reviews/accounts, see: $(a)$ The Lecture Notes in Chemistry 85, in Organometallic Reactions and Polymerization, ed. K. Osakada, Springer-Verlag, Berlin, 2014; (b) K. Nomura and S. Zhang, Chem. Rev., 2011, 111, 2342; (c) H. Makio, H. Terao, A. Iwashita and T. Fujita, Chem. Rev., 2011, 111, 2363; (d) M. Delferro and T. J. Marks, Chem. Rev., 2011, 111, 2450; (e) G. M. Miyake and E.-Y. X. Chen, Polym. Chem., 2011, 2, 2462; (f) C. Redshaw and Y. Tang, Chem. Soc. Rev., 2012, 41, 4484; (g) A. Valente, A. Mortreux, M. Visseaux and P. Zinck, Chem. Rev., 2013, 113, 3836; (h) J. P. McInnis, M. Delferro and T. J. Marks, Acc. Chem. Res., 2014, 47, 2545; (i) J. Klosin, P. P. Fontaine and R. Figueroa, Acc. Chem. Res., 2015, 48, 2004; (j) S. A. Ryken and L. L. Schafer, Acc. Chem. Res., 2015, 48, 2576; (k) B. L. Small, Acc. Chem. Res., 2015, 48, 2599.

4 (a) K. Nomura, J. Liu, S. Padmanabhan and B. Kitiyanan, J. Mol. Catal. A: Chem., 2007, 267, 1; (b) K. Nomura, Dalton Trans., 2009, 8811; (c) K. Nomura and J. Liu, Dalton Trans., 2011, 40, 7666. 
5 (a) D. W. Stephan, Organometallics, 2005, 24, 2548; (b) M. J. Ferreira and A. M. Martins, Coord. Chem. Rev., 2006, 250, 118.

6 (a) Coordination Polymerization, ed. J. C. W. Chien, Academic Press, New York, 1975; (b) A. Andresen, H. G. Cordes, H. Herwig, W. Kaminsky, A. Merk, R. Mottweiler, J. Pein, H. Sinn and H. J. Vollmer, Angew. Chem., Int. Ed. Engl, 1976, 15, 630; (c) H. Sinn, W. Kaminsky, H.-J. Vollmer and R. Woldt, Angew. Chem., Int. Ed. Engl., 1980, 19, 390; (d) H. Sinn and W. Kaminsky, Adv. Organomet. Chem., 1980, 18, 99 .

7 Selected review article, see: (a) A. Macchioni, Chem. Rev., 2005, 105, 2039; (b) M. Bochmann, Organometallics, 2010, 29, 4711; (c) W. Kaminsky, Macromolecules, 2012, 4, 3289; (d) S. Dagorne and C. Fliedel, in Modern Organoaluminium Reagents, Topics in Organometallic Chemistry, ed. S. Woodward and S. Dagorne, Springer-Verlag, BerlinHeidelberg, 2013, vol. 41, p. 125.

8 (a) L. Li, M. V. Metz, H. Li, M.-C. Chen, T. J. Marks, L. LiableSands and A. L. Rheingold, J. Am. Chem. Soc., 2002, 124, 12725; (b) H. Li, L. Li, T. J. Marks, L. Liable-Sands and A. L. Rheingold, J. Am. Chem. Soc., 2003, 125, 10788; (c) N. Guo, L. Li and T. J. Marks, J. Am. Chem. Soc., 2004, 126, 6542; (d) H. Li, L. Li and T. J. Marks, Angew. Chem., Int. Ed., 2004, 43, 4937; (e) H. Li, L. Li, D. J. Schwartz, M. V. Metz, T. J. Marks, L. Liable-Sands and A. L. Rheingold, J. Am. Chem. Soc., 2005, 127, 14756; (f) H. Li and T. J. Marks, Proc. Natl. Acad. Sci. U. S. A., 2006, 103, 15295; $(g)$ N. Guo, C. L. Stern and T. J. Marks, J. Am. Chem. Soc., 2008, 130, 2246; (h) A. Motta, I. L. Fragala and T. J. Marks, J. Am. Chem. Soc., 2009, 131, 3974.

9 (a) S. Liu, A. Motta, M. Delferro and T. J. Marks, J. Am. Chem. Soc., 2013, 135, 8830; (b) S. Liu, A. Motta, A. R. Mouat, M. Delferro and T. J. Marks, J. Am. Chem. Soc., 2014, 136, 10460 .

10 For examples (by aryloxo-modified half-titanocene catalysts), see: (a) K. Nomura, H. Okumura, T. Komatsu and N. Naga, Macromolecules, 2002, 35, 5388; (b) K. Nomura, M. Tsubota and M. Fujiki, Macromolecules, 2003, 36, 3797; (c) W. Wang, M. Fujiki and K. Nomura, J. Am. Chem. Soc., 2005, 127, 4582; (d) K. Nomura, K. Itagaki and M. Fujiki, Macromolecules, 2005, 38, 2053; (e) K. Nomura, K. Itagaki and M. Fujiki, Macromolecules, 2005, 38, 8121; ( $f$ ) F. Z. Khan, K. Kakinuki and K. Nomura, Macromolecules, 2009, 42, 3767; (g) K. Kakinuki, M. Fujiki and K. Nomura, Macromolecules, 2009, 42, 4585; (h) W. Apisuk and K. Nomura, J. Polym. Sci., Part A: Polym. Chem., 2016, 54, 1902; (i) W. Zhao, Q. Yan, K. Tsutsumi and K. Nomura, Organometallics, 2016, 35, 1895.

11 (a) W. Wang, M. Fujiki and K. Nomura, Macromol. Rapid Commun., 2004, 25, 504; (b) P. M. Gurubasavaraj and K. Nomura, Organometallics, 2010, 29, 3500; (c) Y. Takii, P. M. Gurubasavaraj, S. Katao and K. Nomura, Organometallics, 2012, 31, 8237; (d) K. Nomura, U. Tewasekson and Y. Takii, Organometallics, 2015, 34, 3272.

12 Synthesis of aryloxo-modified half-titanocenes supported on carbosilane dendrimers, see: (a) S. Arévalo, J. M. Benito,
E. de Jesús, F. J. de la Mata, J. C. Flores and R. Gómez, J. Organomet. Chem., 2000, 602, 208; (b) S. Arévalo, E. de Jesús, F. J. de la Mata, J. C. Flores and R. Gómez, Organometallics, 2001, 20, 2583; (c) S. Arévalo, E. de Jesús, F. J. de la Mata, J. C. Flores, R. Gómez, M. P. Gómez-Sal, P. Ortega and S. Vigo, Organometallics, 2003, 22, 5109; (d) S. Arévalo, E. de Jesús, F. J. de la Mata, J. C. Flores, R. Gómez, M.-M. Rodrigo and S. Vigo, J. Organomet. Chem., 2005, 690, 4620. Ethylene polymerisation by half-titanocene supported on carbosilane dendrimer, [[CpTiCl ${ }_{2}\{\mathrm{O}-2,6-$ $\left.\left.\left.(\mathrm{MeO})_{2} \mathrm{C}_{6} \mathrm{H}_{2}-4-\left(\mathrm{CH}_{2}\right)_{3} \mathrm{SiMe}_{2}\left(\mathrm{CH}_{2}\right)_{3}\right\}\right]_{2} \mathrm{SiMe}\left(\mathrm{CH}_{2}\right)_{3}\right]_{4} \mathrm{Si}$ and $\left[\mathrm{CpTiCl}_{2}\left\{\mathrm{O}-2-\mathrm{MeC}_{6} \mathrm{H}_{3}-6-\left(\mathrm{CH}_{2}\right)_{2} \mathrm{SiMe}_{2}\left(\mathrm{CH}_{2}\right)_{3}\right\}\right]_{4} \mathrm{Si}$ in the presence of MAO cocatalyst. Latter complex showed the negligible activity.

13 Synthesis of the other trinuclear half-titanocenes, tris-1,3,5$\left[\mathrm{Cp}{ }^{*} \mathrm{Ti}\left(\mathrm{X}_{2}\right) \mathrm{O}\right]_{3} \mathrm{C}_{6} \mathrm{H}_{3}(\mathrm{X}=\mathrm{Cl}, \mathrm{Me})$. S. Arévalo, M. R. Bonillo, E. de Jesús, F. J. de la Mata, J. C. Flores, R. Gómez, P. Gómez-Sal and P. Ortega, J. Organomet. Chem., 2003, 681, 228.

14 Examples for synthesis, structural analysis of aryloxomodified half-titanocenes (related to this study), ${ }^{10 i}$ see: $(a)$ P. Gómez-Sal, A. Martín, M. Mena, P. Royo and R. Serrano, J. Organomet. Chem., 1991, 419, 77; (b) K. Nomura, N. Naga, M. Miki, K. Yanagi and A. Imai, Organometallics, 1998, 17, 2152; (c) K. Nomura, N. Naga, M. Miki and K. Yanagi, Macromolecules, 1998, 31, 7588; (d) S. J. Sturla and S. L. Buchwald, Organometallics, 2002, 21, 739; (e) K. Nomura and A. Fudo, Inorg. Chim. Acta, 2003, 345, 37; (f) K. Nomura, A. Tanaka and S. Katao, J. Mol. Catal. A: Chem., 2006, 254, 197.

15 Additional experiments for reactions of $\mathrm{Cp}^{*} \mathrm{TiCl}_{3}$ or $(1,2,4$ $\left.\mathrm{Me}_{3} \mathrm{C}_{5} \mathrm{H}_{2}\right) \mathrm{TiCl}_{3}$ with [( $\left.\left.\mathrm{LiO}-2,4-\mathrm{Me}_{2} \mathrm{C}_{6} \mathrm{H}_{2}\right)-6-\mathrm{CH}_{2}\right]_{3} \mathrm{~N}$, reaction of $\mathrm{Cp}^{*} \mathrm{TiMe}_{3}$ (generated in situ) with $\left[\left(\mathrm{HO}-2,4-{ }^{t} \mathrm{Bu}_{2} \mathrm{C}_{6} \mathrm{H}_{2}\right.\right.$ )-6$\left.\mathrm{CH}_{2}\right]_{3} \mathrm{~N}$, and additional VT ${ }^{1} \mathrm{H}$ NMR spectra for $\left[\mathrm{CpTiCl}_{2}\left\{\left(\mathrm{O}-2,4-\mathrm{Me}_{2} \mathrm{C}_{6} \mathrm{H}_{2}\right)-6-\mathrm{CH}_{2}\right\}\right]_{3} \mathrm{~N}$ (1) in toluene- $d_{8}$, and ${ }^{1} \mathrm{H} \quad \mathrm{NMR}$ spectra for $\left[\mathrm{Cp}^{\prime} \mathrm{TiCl}_{2}\left\{\left(\mathrm{O}-2,4-\mathrm{Me}_{2} \mathrm{C}_{6} \mathrm{H}_{2}\right)-6-\mathrm{CH}_{2}\right\}\right]$ $\left[\mathrm{Cp}^{\prime} \mathrm{TiCl}\left\{\left(\mathrm{O}-2,4-\mathrm{Me}_{2} \mathrm{C}_{6} \mathrm{H}_{2}\right)-6-\mathrm{CH}_{2}\right\}_{2}\right] \mathrm{N}\left[\mathrm{Cp}^{\prime}=\mathrm{Cp}^{*}(2), 1,2,4-\right.$ $\left.\mathrm{Me}_{3} \mathrm{C}_{5} \mathrm{H}_{2}(3)\right]$, and $\left[\mathrm{Cp}^{\prime} \mathrm{TiCl}_{2}\left\{\left(\mathrm{O}-2,4-\mathrm{R}_{2} \mathrm{C}_{6} \mathrm{H}_{2}\right)-6-\mathrm{CH}_{2}\right\}\right]_{3} \mathrm{~N}[\mathrm{R}=$ $\mathrm{Me}, \mathrm{Cp}^{\prime}=\mathrm{Cp}(\mathbf{1}) ; \mathrm{R}={ }^{t} \mathrm{Bu}, \mathrm{Cp}^{\prime}=\mathrm{Cp}(\mathbf{4}), \mathrm{Cp}^{*}(\mathbf{5}),{ }^{t} \mathrm{BuC}_{5} \mathrm{H}_{4}$ (6), 1,2,4- $\mathrm{Me}_{3} \mathrm{C}_{5} \mathrm{H}_{2}$ (7)] upon heating in toluene- $d_{8}$ at $80{ }^{\circ} \mathrm{C}$ (for $30 \mathrm{~min}$ ) are shown in the ESI. $\dagger$

16 L. Michalczyk, S. de Gala and J. W. Bruno, Organometallics, 2001, 20, 5547.

17 Structural reports for $\left[\mathrm{CpTiCl}_{2}\left\{\left(\mathrm{O}-2,4-\mathrm{Me}_{2} \mathrm{C}_{6} \mathrm{H}_{2}\right)-6-\mathrm{CH}_{2}\right\}\right]_{3} \mathrm{~N}$ (1), $\left[\mathrm{Cp}^{\prime} \mathrm{TiCl}_{2}\left\{\left(\mathrm{O}-2,4-{ }^{t} \mathrm{Bu}_{2} \mathrm{C}_{6} \mathrm{H}_{2}\right)-6-\mathrm{CH}_{2}\right\}\right]_{3} \mathrm{~N} \quad\left[\mathrm{Cp}^{\prime}=\mathrm{Cp}\right.$ (4), $\mathrm{Cp}^{*}$ (5), 1,2,4- $\mathrm{Me}_{3} \mathrm{C}_{5} \mathrm{H}_{2}$ (7)], $\left[\mathrm{Cp}^{\prime} \mathrm{TiCl}_{2}\left\{\left(\mathrm{O}-2,4-\mathrm{Me}_{2} \mathrm{C}_{6} \mathrm{H}_{2}\right)-6-\right.\right.$ $\left.\left.\mathrm{CH}_{2}\right\}\right]\left[\mathrm{Cp}^{\prime} \mathrm{TiCl}\left\{\left(\mathrm{O}-2,4-\mathrm{Me}_{2} \mathrm{C}_{6} \mathrm{H}_{2}\right)-6-\mathrm{CH}_{2}\right\}_{2}\right] \mathrm{N} \quad\left[\mathrm{Cp}^{\prime}=\mathrm{Cp}^{*}\right.$ (2), 1,2,4- $\left.\mathrm{Me}_{3} \mathrm{C}_{5} \mathrm{H}_{2} \quad(3)\right]$, and $\left[\mathrm{Cp}^{*} \mathrm{TiMe}_{2}\left\{\left(\mathrm{O}-2,4-{ }^{t} \mathrm{Bu}_{2} \mathrm{C}_{6} \mathrm{H}_{2}\right)-6-\right.\right.$ $\left.\left.\mathrm{CH}_{2}\right\}\right]_{3} \mathrm{~N}$ (9) are shown in the ESI. $\dagger$ CCDC numbers for complexes 1-5, 7 and 9 are CCDC 1549581-1549587, respectively. $\dagger$

18 Additional ethylene polymerisation results including confirmation of reproducibility are shown in the ESI. $\dagger$

19 CrystalClear: Data Collection and Processing Software, Rigaku Corporation, Tokyo 196-8666, Japan, 1998-2015.

20 CrysAlisPro: Data Collection and Processing Software, Rigaku Corporation, Tokyo 196-8666, Japan, 1998-2015. 
21 (a) G. M. Sheldrick, SHELXT, Acta Crystallogr., Sect. A: Found. Adv., 2014, 70, C1437; (b) A. Altomare, G. Cascarano, C. Giacovazzo and A. Guagliardi, SIR92, J. Appl. Crystallogr., 1993, 26, 343.
22 Crystal Structure 4.2: Crystal Structure Analysis Package, Rigaku Corporation, Tokyo 196-8666, Japan, 2000-2015.

23 G. M. Sheldrick, SHELXL Version 2014/7, Acta Crystallogr., Sect. A: Found. Crystallogr., 2008, A64, 112. 